\title{
Determination of endocrine disrupting chemicals and antiretroviral compounds in surface water: a disposable sorptive sampler with comprehensive gas chromatography - time-of-flight mass spectrometry and large volume injection with ultra-high performance liquid chromatography - tandem mass spectrometry
}

Madelien Wooding, Egmont R. Rohwer, Yvette Naudé*

Department of Chemistry, University of Pretoria, Private Bag X20, Hatfield 0028, Pretoria, South Africa

*Corresponding author. Tel.: +27 12420 2517; fax: +27 12420 4687; yvette.naude@up.ac.za.

\section{ABSTRACT}

Many rural dwellers and inhabitants of informal settlements in South Africa are without access to treated water and collect untreated water from rivers and dams for personal use. Endocrine disrupting chemicals (EDCs) have been detected in surface water and wildlife of South Africa. EDCs are often present in complex environmental matrices at ultra-trace levels complicating detection thereof. We report a simplified multi-residue approach for the detection and quantification of EDCs, emerging EDCs, and antiretroviral drugs in surface water. A low cost (less than one US dollar), disposable, sorptive extraction sampler was prepared in-house. The disposable samplers consisted of polydimethylsiloxane (PDMS) tubing fashioned into a loop which was then placed in water samples to concentrate EDCs and emerging pollutants. The PDMS samplers were thermally desorbed directly in the inlet of a GC, thereby eliminating the need for expensive consumable cryogenics. Comprehensive gas chromatography coupled to time-of-flight mass spectrometry (GC×GC-TOFMS) was used for compound separation and identification. Linear retention indices of EDCs and emerging pollutants were determined on a proprietary Crossbond® phase Rtx®-CLPesticides II GC capillary column. In addition, large volume injection of surface water into an ultra-performance liquid chromatograph tandem mass spectrometer (UPLC-MS/MS) was used as complementary methodology for the detection of less volatile compounds. Large volume injection reduced tedious and costly sample preparation steps. Limits of detection for the GC method ranged from 1 to $98 \mathrm{pg} / \mathrm{l}$ and for the LC method from 2 to $135 \mathrm{ng} / \mathrm{l}$. Known and emerging EDCs such as pharmaceuticals, personal care products and pesticides, as well as the antiretroviral compounds, efavirenz and nevirapine, were detected in surface water from South Africa at concentration levels ranging from $0.16 \mathrm{ng} / \mathrm{l}$ to $227 \mathrm{ng} / \mathrm{l}$.

Keywords: Disposable PDMS sampler; Antiretroviral compounds; Endocrine Disrupting Chemicals; Surface water; GCXGC-TOFMS; UHPLC-MS/MS 


\section{Introduction}

The exposure of rural communities in South Africa to untreated surface water through lack of water sanitation services, or by accidental contact, has raised concern due to the potential health risks associated with aquatic contaminants. Although many rural dwellers and inhabitants of informal settlements are compelled to use untreated water from rivers and dams there are currently no guidelines to monitor the quality of untreated river water in South Africa as it is not considered a source for human consumption [1]. Annually, complex mixtures of chemicals are released into the aquatic systems by industries, agriculture and private households [2]. Chemical pollutants that are harmful to human and animal health, because of their biological effect, are classified as endocrine disrupting chemicals (EDCs) [3]. According to the World Health Organization (2012) an EDC is "an exogenous substance or mixture that alters function(s) of the endocrine system and consequently causes adverse health effects in a intact organism, or its progeny, or (sub) populations" [4]. Varying concentrations of EDCs have been found in surface water, such as dams and rivers, and wastewaters in South Africa [2, 5-8]. Aneck-Hahn et al. (2009) reported oestrogenic activity in drinking water in two rural areas in the Limpopo Province, South Africa [6]. Oestrogenic activity was also reported in water sources at Rietvlei Nature Reserve, Pretoria, South Africa [2].

EDCs include a range of compounds with different physico-chemical properties [9]. Major sources of EDCs include phthalates, polychlorinated biphenyls, polycyclic aromatic hydrocarbons (PAHs), brominated flame retardants, pesticides, dioxins, hormones, pharmaceuticals and personal care products $[10,11]$. EDC analysis is challenging as EDCs comprise of a diverse group of chemical compounds found at trace levels in complex environmental matrices [12]. Current approaches for EDC extraction and detection require either multiple extractions, large sample volumes, derivatisation or extensive clean up [13]. The majority of methods focus on a specific class of compound (.e.g. oestrogen steroids) [9, 13]. There is a need for a comprehensive multi-residue approach for the quantitative determination of EDCs at trace levels in water matrices while minimizing sample preparation time and cost [9]. In addition to EDCs, the presence of pharmaceuticals such as antiretroviral compounds used for the treatment of the human immunodeficiency virus (HIV) has been reported in surface water across South Africa [14].

Sample preparation steps are often time consuming, costly and labour intensive. Classical liquid-liquid extraction, solvent evaporation and steam distillation methods are being replaced by more effective and versatile techniques such as solid phase extraction (SPE), solid phase micro extraction (SPME) and stir bar sorptive extraction (SBSE) [9, 12, 15]. Endocrine disrupting pesticides (EDPs) may be extracted using the QuEChERS (quick, easy, cheap, effective, rugged and safe) approach developed by Anastassiades et al. (2003) [16, 17]. However, the QuEChERS approach requires solvent usage [17]. Although SPE is an effective technique a potential disadvantage is injection of only an aliquot (microlitre amounts) of the final solvent extract into the analytical instrument [18]. In 
order to overcome possible sensitivity shortcomings of solvent-based extraction techniques sorptive sampling techniques coupled to thermal desorption in combination with gas chromatography (GC) are preferred [17, 18]. SPME and SBSE are commercial solvent free sorptive extraction techniques. SPME was introduced by Arthur and Pawliszyn in 1990 to eliminate the problems associated with SPE such as high blank values and variation in the cartridge composition [19]. Depending on application, the low sorptive volume of SPME (sorbent volumes up to $0.5 \mu \mathrm{l}$ ) may be a limitation despite it being easy to use and low in cost [18]. The potential sensitivity drawback of sorptive samplers such as SPME was overcome with the introduction of SBSE (developed by Baltussen and Sandra in 1999) [20]. Sorptive volumes of up to $200 \mu \mathrm{l}$ for SBSE have allowed for a sensitivity increase of up to 500-fold when compared to SPME enabling quantitative extraction of analytes from aqueous samples $[18,20]$. Polydimethylsiloxane (PDMS) is most commonly used as sorbent for sorptive extraction. PDMS is inert, stable during thermal desorption, reproducible due to consistency between manufacturers, and degradation products can easily be tracked and identified [18]. When developing customised samplers the use of bulk low cost PDMS gives the user control over the choice of sorbent volume and creation of application specific sorptive samplers. The low cost of the sorbent material allows disposable samplers, thereby avoiding difficulties with carry-over and cross contamination [21]. The hydrophobicity of PDMS enables high recovery of hydrophobic compounds. However, polar compounds show lower recovery. To overcome this limitation Ochiai et al. (2008) developed a sequential salting out extraction procedure for multi-residue analysis [22]. This approach provides uniform enrichment over the entire polarity range for organic pollutants at trace level in water [22].

The most comprehensive and powerful multi-residue methods to detect contaminants at trace levels are the combination of gas chromatography - mass spectrometry (GC-MS) and liquid chromatography - mass spectrometry (LC-MS). The two methodologies may be used complementary in order to expand the range of detectable compounds. Comprehensive two-dimensional gas chromatography $(G C \times G C)$ is ideal for the investigation of complex environmental matrices as it provides more separation power and improved sensitivity when compared to conventional GC [23]. Comprehensive two-dimensional gas chromatography with time-of-flight mass spectrometry (GC $\times$ GC-TOFMS) provides the possibility of doing untargeted analysis of various compounds in complex matrices $[17,23]$. Ultra-high pressure chromatography (UHPLC) delivers better chromatographic resolution and increased peak capacity due to the use of sub-2 $\mu \mathrm{m}$ column particles when compared to conventional HPLC. UHPLC is often used for fast multi-residue screening of organic contaminants in environmental samples [23]. The use of UHPLC coupled with tandem mass spectrometry (MS/MS) such as the triple quadrupole (QqQ) permits the development of faster and more sensitive methods, especially for target analysis [24]. However, high resolution mass spectrometry (HRMS) analysers such as time-of-flight (TOF) allow for improved identification during broad range screening. The quadrupole time-of-flight (QTOF) instrument provides the user with the option to acquire full scan MS spectra and MS/MS spectra for high confidence identification of compounds [25]. QTOF technology 
has previously been used by Masiá et al. (2014) and Bueno et al. (2012) for target and non-target screening of contaminants in water [25, 26]. Large volume injection (LVI) involves the direct injection of sample volumes that range from 100 to $5000 \mu \mathrm{l}$ compared to conventional injection volumes of 10 to $20 \mu \mathrm{l}$. The injection of larger sample volumes increases sensitivity and reduces sample handling steps resulting in greater reproducibility [24, 27]. LVI with UHPLC was recently applied by Boix et al. (2015) for the determination of 40 drugs from water [24]; and LVI with LC was applied by Bayen et al. (2014) for the analysis of antibiotics in surface freshwater and seawater [28]. However, matrix effects need to be considered when using LVI as complex environmental samples can interfere with the electrospray ionization (ESI) process $[24,27]$. Good separation and matrix matched standardisation are required for reliable quantification [17].

We report solvent free extraction using an in-house developed, disposable PDMS sorptive sampler with thermal desorption thereof directly in the inlet liner of a GC for analysis with GC×GCTOFMS; and LVI with UHPLC-MS/MS for the simplified determination of EDCs and emerging contaminants, such as antiretroviral drugs, in surface water from rural and metropolitan areas of South Africa.

\section{Materials and methods}

\subsection{Sample collection and preservation}

Surface water samples were collected on 6/2/2015 for targeted and untargeted analysis at six different sites in Rietvlei Nature Reserve, Pretoria, South Africa. Follow-up sampling took place on $15 / 3 / 2016$ at the same six sampling sites at Rietvlei Nature Reserve. Rietvlei Nature Reserve is situated $20 \mathrm{~km}$ south of the central business district of Pretoria, South Africa. The reserve functions as a catchment area for the Rietvlei Water Purification Works. Two large dams are located in the Reserve, namely the Rietvlei Dam and upstream from it the Marais Dam. The Marais Dam acts as a sludge dam which catches wastewater from a nearby sewage treatment plant, industries and informal settlements. Water from the Rietvlei Dam is treated by the Rietvlei Water Purification Works which is used as drinking water for Pretoria [2]. Surface water sampling was also conducted on 17/8/2015 at the Albasini Dam, Limpopo Province, South Africa. The dam is located in a rural area of the Limpopo Province where the organochlorine insecticide, DDT, is used for malaria vector control. Indoor residual spraying of traditional dwellings with DDT is allowed under the Stockholm Convention on Persistent Organic Pollutants (POPs) [29, 30].

At each site $1 \mathrm{~L}$ surface water was collected in glass bottles for extraction in the laboratory. All samples were collected in glass Schott bottles (Duran ${ }^{\circledR}$, Sigma-Aldrich, South Africa), the opening sealed with foil and then screwed closed. Methanol (Merck, South Africa) was added to a final concentration of $5 \%(\mathrm{v} / \mathrm{v})$ as a preservative to samples used for untargeted screening. Methanol was 
not added to samples extracted using the salting out technique (2.5.1). Samples were stored at $4{ }^{\circ} \mathrm{C}$ prior to analysis.

2.2. Reagents and certified reference standards

\subsubsection{Reagents}

Methanol $(\mathrm{MeOH}), n$-hexane, toluene, de-ionised water, ethyl acetate, acetonitrile $(\mathrm{ACN})$, acetone and sodium chloride $(\mathrm{NaCl})$ were all purchased from Merck, South Africa. LC-MS ultra CHROMASOLV ${ }^{\circledR}$ water with $0.1 \%$ formic acid and LC-MS CHROMASOLV $®$ acetonitrile with $0.1 \%$ formic acid (Fluka ${ }^{\circ}$ Analytical, Sigma-Aldrich, South Africa) were used for UHPLC-MS/MS analysis. For GC linear retention index determination $n$-alkanes $C_{12}-C_{28}$ were used (Merck, Pretoria, South Africa).

\subsubsection{Certified reference standards}

Nevirapine (United States Pharmacopeia (USP) standard) and efavirenz (USP standard) were supplied by Tim Wood (Protechnik Laboratories, South Africa). Caffeine solution $(1.0 \mathrm{mg} / \mathrm{mL}$ in $\mathrm{MeOH})$, atrazine (PESTANAL ${ }^{\circledR}$, analytical standard, purity $98.8 \%$ ), chlorpyrifos (PESTANAL $®$, analytical standard, purity $99.7 \%$ ), musk ketone solution (100 $\mathrm{ng} / \mu \mathrm{l}$ in acetonitrile, analytical standard, $95 \mathrm{ng} / \mu \mathrm{L} \pm 5 \%$ ), lindane (PESTANAL $®$, analytical standard, purity $99.8 \%$ ), metolachlor (PESTANAL ${ }^{\circledR}$, analytical standard, purity $97.6 \%$ ) and terbuthylazine (PESTANAL ${ }^{\circ}$, analytical standard, purity $99.4 \%$ ) were all purchased from Fluka ${ }^{\circledR}$ Analytical, Sigma-Aldrich, South Africa. Terbutryn (purity $98.1 \%$ ) was purchased from Supelco® Analytical, Sigma-Aldrich, South Africa and acetaminophen (analytical standard) was purchased from Sigma-Aldrich, South Africa. 4-tert-Amylphenol (purity 99.5\%) was purchased from Dr. Ehrenstorfer, Augsburg, Germany.

\subsection{Standard solutions}

\subsubsection{Stock solutions}

Individual stock solutions of $100 \mu \mathrm{g} / \mathrm{ml}$ were prepared by dissolving $5 \mathrm{mg}$ powder in $50 \mathrm{~mL}$ (or $2.5 \mathrm{mg}$ powder in $25 \mathrm{ml}$ ) of methanol or toluene depending on their solubility. All standards, except for musk ketone, caffeine and acetaminophen, were dissolved in toluene. A small amount of ethyl acetate and/or methanol was added to terbutryn, metolachlor, terbuthylazine, chlorpyrifos, lindane and 4-tert-amylphenol to aid in solvation. A $100 \mu \mathrm{g} / \mathrm{ml}$ stock solution of efavirenz was prepared in toluene $(2.5 \mathrm{mg}$ powder in $25 \mathrm{ml})$. A $70 \mu \mathrm{g} / \mathrm{ml}$ stock solution of nevirapine was prepared in toluene $(3.5 \mathrm{mg}$ powder in $50 \mathrm{ml})$. All the stock solutions were stored in glass vials and kept at $4{ }^{\circ} \mathrm{C}$. 


\subsubsection{Working and spiking solutions}

Working standard solutions containing a mixture of the target analytes were prepared at two concentration levels ( 1 and $5 \mu \mathrm{g} / \mathrm{ml}$ ) by combining suitable aliquots of each individual stock solution and diluting it with $n$-hexane $(1 \mu \mathrm{g} / \mathrm{ml}$ for GCxGC-TOFMS) or acetonitrile (5 $\mu \mathrm{g} / \mathrm{ml}$ for UHPLC-MS/MS) to a final volume of $1 \mathrm{ml}$. Stock solutions purchased in $\mathrm{MeOH}$ required a four-fold dilution with toluene before being miscible with $n$-hexane. Working solutions were stored in glass vials and kept at $4{ }^{\circ} \mathrm{C}$. Spiking solutions for the matrix matched calibrations of the GCXGC-TOFMS were prepared at three different levels of concentration $(0.5,0.05$ and $0.01 \mu \mathrm{g} / \mathrm{ml})$ by diluting aliquots of the $1 \mu \mathrm{g} / \mathrm{ml} n$-hexane solution with acetone (miscible with water) to a final volume of $1 \mathrm{ml}$.

2.4. Matrix matched calibrations

\subsubsection{GC $\times$ GC-TOFMS}

Matrix matched calibration curves of reference compounds were constructed by spiking $50 \mathrm{ml}$ de-ionised water at concentration levels of $0 \mathrm{ng} / \mathrm{l}, 0.2 \mathrm{ng} / \mathrm{l}(1 \mathrm{ul}$ added from 0.01 $\mu \mathrm{g} / \mathrm{ml}), 0.5 \mathrm{ng} / \mathrm{l}(0.5 \mu \mathrm{l}$ added from $0.05 \mu \mathrm{g} / \mathrm{ml}), 1 \mathrm{ng} / \mathrm{l}(1 \mu \mathrm{l}$ added from $0.05 \mu \mathrm{g} / \mathrm{ml}), 1.5 \mathrm{ng} / \mathrm{l}$ (1.5 $\mu \mathrm{l}$ added from $0.05 \mu \mathrm{g} / \mathrm{ml}), 2 \mathrm{ng} / \mathrm{l}(2 \mu \mathrm{l}$ added from $0.05 \mu \mathrm{g} / \mathrm{ml}), 5 \mathrm{ng} / \mathrm{l}(0.5 \mu \mathrm{l}$ added from $0.5 \mu \mathrm{g} / \mathrm{ml}), 10 \mathrm{ng} / \mathrm{l}(1 \mu \mathrm{l}$ added from $0.5 \mu \mathrm{g} / \mathrm{ml}), 20 \mathrm{ng} / \mathrm{l}(2 \mu \mathrm{l}$ added from $0.5 \mu \mathrm{g} / \mathrm{ml}), 40 \mathrm{ng} / \mathrm{l}(4$ $\mu \mathrm{l}$ added from $0.5 \mu \mathrm{g} / \mathrm{ml}$ ) to give a calibration range from 0 to $40 \mathrm{ng} / \mathrm{l}$. Spiking solutions were in acetone (2.3.2). The spiked samples were left to stand for 30 minutes to equilibrate before extraction commenced (2.5.1). A reconstructed ion chromatogram of the matrix blank can be found in the supplementary material (Figure A).

\subsubsection{UHPLC-MS/MS}

Matrix matched calibration curves for LVI were constructed (range $0-10000 \mathrm{ng} / \mathrm{l}$ ) by spiking $100 \mathrm{ml}$ de-ionised water at concentration levels of $0 \mathrm{ng} / \mathrm{l}, 10 \mathrm{ng} / \mathrm{l}(0.2 \mu \mathrm{l}$ added from 5 $\mu \mathrm{g} / \mathrm{ml}), 100 \mathrm{ng} / \mathrm{l}(2 \mu \mathrm{l}$ added from $5 \mu \mathrm{g} / \mathrm{ml}), 1000 \mathrm{ng} / \mathrm{l}(20 \mu \mathrm{l}$ added from $5 \mu \mathrm{g} / \mathrm{ml}), 2500 \mathrm{ng} / \mathrm{l}$ (50 $\mu \mathrm{l}$ added from $5 \mu \mathrm{g} / \mathrm{ml}), 5000 \mathrm{ng} / \mathrm{l}(100 \mu \mathrm{l}$ added from $5 \mu \mathrm{g} / \mathrm{ml}), 10000 \mathrm{ng} / \mathrm{l}(200 \mu \mathrm{l}$ added from $5 \mu \mathrm{g} / \mathrm{ml}$ ) using the $5 \mu \mathrm{g} / \mathrm{ml}$ acetonitrile composite working standard solution and directly injecting $100 \mu \mathrm{l}$ of the sample into the LC (2.6.2). Reconstructed ion chromatograms of the matrix matched standards $0 \mathrm{ng} / \mathrm{l}$ and $5000 \mathrm{ng} / \mathrm{l}$ can be found in the supplementary material (Figure B).

\subsection{Sample preparation and pre-concentration for GCxGC-TOFMS}




\subsubsection{Sorptive extraction with sequential salting out}

A disposable sampler was manufactured in-house for sorptive extraction of analytes from surface water. The sampler had been previously developed for solvent free extraction of soil $[29,31]$ and recently used by Naudé and co-workers as a passive sampler to concentrate pollutants from surface water [32]. This study is the first to characterise the trace quantitative characteristics of the PDMS loop sampler. The sampler $(0.03 \pm 0.002 \mathrm{~g})$ was fashioned (as described by Naudé et al. (2015)) by forming a loop with a $10.5 \mathrm{~cm}(0.03 \mathrm{~g})$ length of a silicone elastomer medical grade tubing $(0.64 \mathrm{~mm}$ OD $\times 0.3 \mathrm{~mm}$ ID, Sil-Tec®, Technical Products, Georgia, USA). The ends were joined by inserting a $1 \mathrm{~cm}$ piece of uncoated silica capillary column (250 $\mu \mathrm{m}$ ID) (SGE Analytical Science, Separation Scientific (Pty) Ltd, Roodepoort, South Africa) (Fig. 1). The loop arrangement keeps water from entering the polydimethylsiloxane (PDMS) tubing and aids ease of handling. The sorption volume of the loop was $26 \mu \mathrm{L}$ [32]. Prior to extraction the PDMS sampling loops were cleaned using the method outlined by Triñanes et al. (2015) for cleaning silicone sampling disks [21].



Figure 1. Disposable PDMS sampling loop: a $10 \mathrm{~cm}$ length of a silicone elastomer medical grade tubing joined at the ends by a $1 \mathrm{~cm}$ piece of uncoated silica capillary column. See section 2.5.1. The $3 \mathrm{~cm}$ paper clip is for size indication.

The multi-residue method developed and optimised by Pintado-Herrera et al. (2014) for the extraction of a range of contaminants from aqueous matrices using SBSE was adapted [33]. Optimized conditions were established at an agitation time of 5 hours, addition of $10 \% \mathrm{NaCl}$ and without the addition of methanol by Pintado-Herrera et al. (2014). Water samples $(500 \mathrm{~mL})$ were placed in Schott glass bottles. Salt $(10 \% \mathrm{NaCl})$ was added sequentially using the method outlined by Ochiai et al. (2008) [22]. A PDMS loop was secured with a stainless steel wire on a glass stirrer bar (Spinbar® Pyrex ${ }^{\circledR}$ magnetic stir bar, size $2.54 \mathrm{~cm} \times 0.95 \mathrm{~cm}$, Sigma-Aldrich, USA) and immersed in the water sample (Fig. 2). The opening of the bottle was sealed with foil and closed with a screw cap. Stirring commenced for 5 hours at room temperature at a stirring rate of $300 \mathrm{rpm}$ using a magnetic stirrer plate, whereafter the sampler was removed with a clean stainless steel tweezer, dried with a lint free tissue and placed in a capped glass vial. The glass vial was temporarily stored at $4{ }^{\circ} \mathrm{C}$. After removal of the sampler, $10 \% \mathrm{NaCl}(\mathrm{w} / \mathrm{v})(50 \mathrm{~g}$ per $500 \mathrm{~mL}$ sample) was dissolved in the sample and a second 
sampler was placed in the sample. The second extraction was performed under the same conditions as the first extraction. After the second extraction was completed the sampler was removed with a clean stainless steel tweezer and dried with a lint free tissue. The two samplers were transferred into the inlet liner of a GC inlet for thermal desorption (TD) (Fig. 3) (2.6.1).



Figure 2. Sorption extraction: PDMS sampling loop secured to a glass stir bar using stainless steel wire. See section 2.5.1.

\subsubsection{Large volume injections for UHPLC-MS/MS}

The LVI method was based on work done by Bayen et al. (2014) and Boix et al. (2015). The water samples (1 $\mathrm{ml}$ each in an Eppendorf tube) were centrifuged at $6000 \mathrm{rpm}$; work force $2000 \mathrm{~g}$ (BG-QspinTM Hand Centrifuge, Vacutec, South Africa) before injection. A $100 \mu \mathrm{l}$ of the sample was directly injected into the LC for analysis. The LC was fitted with a $100 \mu \mathrm{l}$ sample loop and a $250 \mu \mathrm{l}$ syringe (Waters Inc., Milford, Massachusetts, USA).

2.6. Chromatographic analysis

\subsubsection{GC $\times$ GC-TOFMS}

Separation of compounds was performed on a LECO Pegasus ${ }^{\circledR}$ 4D GC $\times G C$-TOFMS system (LECO Africa (Pty) Ltd., Kempton Park, South Africa). The system consisted of an Agilent $\odot 7890$ GC modified to contain a dual stage modulator and secondary oven. Nitrogen gas cooled with liquid nitrogen was used for the cold jets and synthetic air for the hot jets. ChromaTOF ${ }^{\circledR}$ software (version 4.50.8.0 optimised for Pegasus ${ }^{\circledR}$ ) was used to operate the instrument and for data capturing and processing.

Tentative identification of compounds for untargeted analysis was based on comparison of fullrange mass spectra recorded for the compounds in the samples to that contained in the NIST14 mass spectral library (version 2.2). Compounds with a spectral match quality in the range $80 \%-96.6 \%$ were reported. For targeted analysis unequivocal identification of compounds was based on the comparison of full range mass spectra 
recorded for the compounds in the samples with those recorded for neat certified reference standards and matrix-matched calibration standards, and also by comparison with spectra contained in the NIST14 mass spectral library. In addition, retention time matching was used between compounds in the samples and those in neat certified reference standards and matrix-matched calibration standards. The criterion set for mass spectral matching was $\geq 80 \%$. The mass spectral matches for the targeted compounds were in the range 80\%-96.7\%. The retention time window criterion for first dimension retention time matching was set at $3 \mathrm{~s}$ (1 modulation period) and the retention time window criterion for second dimension retention time matching was set at $0.1 \mathrm{~s}$.

The quantification function of the ChromaTOF $®$ software was used to set up a multilevel calibration table and for quantification. For each compound the primary ion was chosen as the quantification ion for peak area calculation. Peak area calculation was performed by the software.

The column set consisted of a proprietary Crossbond ${ }^{\circledR}$ phase Rtx®-CLPesticides II $30 \mathrm{~m} \times 0.25 \mathrm{~mm}$ ID $\times 0.2 \mu \mathrm{m}$ film thickness (fused silica) as the primary column (1D) joined to a Rxiß-17Sil MS $1 \mathrm{~m} \times 0.25 \mathrm{~mm}$ ID $\times 0.25 \mu \mathrm{m}$ film thickness secondary column (2D) (Restek, Bellefonte, PA, USA). The primary column was connected to the secondary column with a presstight column connector (Restek, Bellefonte, PA, USA). The primary oven temperature programme was $70{ }^{\circ} \mathrm{C}$ (hold for $1.5 \mathrm{~min}$ ) at $10{ }^{\circ} \mathrm{C} / \mathrm{min}$ to $300{ }^{\circ} \mathrm{C}$ (hold for $10 \mathrm{~min}$ ). The GC run time was $34.5 \mathrm{~min}$. The secondary oven was offset by $+10^{\circ} \mathrm{C}$ relative to the primary oven. The modulator temperature was offset $15{ }^{\circ} \mathrm{C}$ relative to the second oven temperature. The modulation period was $3 \mathrm{~s}$ with a hot pulse time of $0.75 \mathrm{~s}$. The carrier gas (helium 5.0, Afrox, South Africa) flow rate was $1.4 \mathrm{~mL} / \mathrm{min}$ in the constant flow mode. The MS transfer line temperature was set at $300^{\circ} \mathrm{C}$. The ion source temperature was $230^{\circ} \mathrm{C}$, the electron energy was $70 \mathrm{eV}$ in the electron ionisation mode (El+), the data acquisition rate was 100 spectra/s, the mass acquisition range was 40-650 Daltons ( $\mathrm{Da}$ ), and the detector voltage was set at 1570 V. The PDMS loops were inserted into a splitless glass inlet liner (Agilent Chemetrix, Midrand, South Africa) (Fig. 3) and desorbed at $250^{\circ} \mathrm{C}$ with a splitless time of 1 min: the hot inlet liner was manually removed from the GC inlet using a pair of tweezers. The PDMS sampler loops were then inserted into the inlet liner, the liner was placed back into the GC inlet and the run was started.



Figure 3. GC inlet liner with two PDMS sampling loops (after sequential salting out extraction (2.5.1)) inserted for direct desorption inside a GC inlet of a GCxGC-TOFMS (2.6.1). 
Linear retention indices were determined by analysing a mixture of $n$-alkanes $\left(\mathrm{C}_{12^{-}}\right.$ $\mathrm{C}_{28}$ ). Experimental linear retention indices were calculated for non-target compounds according to the method of van den Dool and Kratz (1963) [34].

\subsubsection{UHPLC-MS/MS}

Compound separation and detection was performed using a Waters ${ }^{\circledR}$ Synapt G2 high definition mass spectrometry (HDMS) system (Waters Inc., Milford, Massachusetts, USA). The system comprised of a Waters Acquity UPLC® hyphenated to a quadrupole-time-of-flight (QTOF) instrument. The system was operated with MassLynxTM (version 4.1) software (Waters Inc., Milford, Massachusetts, USA) for data acquisition and processing. For each target compound the accurate mass molecular ions $(\mathrm{M}+\mathrm{H})^{+}$were selected as the quantification ions for peak area calculation. Unambiguous identification of target analytes was achieved using retention times matching, accurate mass and MS/MS fragmentation patterns of neat certified standards and matrix-matched standards. QuanLynx Method Editor V4.1 was used to set-up the calibration table and to perform quantification. The retention widow criterion was set at $0.2 \mathrm{~min}$ and the mass window criterion was set at $0.02 \mathrm{Da}$.

An internal lock mass control standard, $2 \mathrm{pg} / \mu \mathrm{l}$ solution leucine enkephalin $(\mathrm{m} / \mathrm{z}$ 555.2693), was directly infused into the source through a secondary orthogonal electrospray ionisation (ESI) probe allowing intermittent sampling. The instrument was calibrated using sodium formate clusters and Intellistart functionality (mass range $112.936-1132.688 \mathrm{Da}$ ). Resolution of 20000 at $\mathrm{m} / \mathrm{z} 200$ (full width at half maximum (FWHM)) and mass error within 5 mDa were obtained.

Separation was completed using a reverse phase step gradient elution scheme from $95 \% \mathrm{H}_{2} \mathrm{O}(0.1 \%$ formic acid) to $100 \%$ acetonitrile $(0.1 \%$ formic acid). The column temperature was kept constant at $40{ }^{\circ} \mathrm{C}$ and the flow rate was set at $0.3 \mathrm{~mL} / \mathrm{min}$ for the entire run giving a total run time of $17 \mathrm{~min}$ and gradient run time of $13 \mathrm{~min}$. A Waters UPLC ${ }^{8} \mathrm{C}_{18}$ Ethylene Bridged Hybrid (BEH) $1.7 \mu \mathrm{m}$ particle size (2.1 mm ID x $100 \mathrm{~mm}$ length) column was used.

The source conditions were as follows: the corona discharge electrode was set at 5 $\mu \mathrm{A}$ for atmospheric pressure chemical ionization (APCI). The probe temperature for $\mathrm{APCl}$ was set at $550{ }^{\circ} \mathrm{C}$. The source temperature was set at $110^{\circ} \mathrm{C}$, the sampling cone voltage at $25 \mathrm{~V}$, extraction cone voltage at $4.0 \mathrm{~V}$ and cone gas (nitrogen) flow at $10.0 \mathrm{~L} / \mathrm{Hr}$. The desolvation temperature was set at $300{ }^{\circ} \mathrm{C}$ with a gas (nitrogen) flow of $600.0 \mathrm{~L} / \mathrm{Hr}$. Mass spectral scans were collected every 0.3 seconds. The raw data was collected in the form of a continuous profile. Mass to charge ratios $(\mathrm{m} / \mathrm{z})$ between 50 and $1200 \mathrm{Da}$ were recorded. Tandem MS $\left(\mathrm{MS}^{\mathrm{E}}\right)$ fragmentation was performed using high energy collision induced dissociation (CID). The fragmentation energy was set at $2 \mathrm{~V}$ and $3 \mathrm{~V}$ for the trap and collision energy, respectively. The ramping was set from 3 to $4 \mathrm{~V}$ and 20 to $40 \mathrm{~V}$ for the trap and transfer collision energy, respectively. 


\section{Results and discussion}

\subsection{Untargeted analysis: GC×GC-TOFMS}

An untargeted screening of surface water from Rietvlei Nature Reserve and Albasini Dam, using solvent free extraction with the PDMS sampling loop and TD of the sampler directly in the GC inlet liner followed by GC×GC-TOFMS analysis, yielded an extensive list of pollutants. Over 3000 compounds were detected due to the superior resolving power and increased sensitivity of GC×GCTOFMS. Compounds detected included personal care products (e.g. the EU and USA banned substance Triclosan), pharmaceuticals, sunscreen ingredients, pesticides, hormones and fragrances, with many of these emerging or classified EDCs. Selected compounds and experimental linear retention indices $\left(R l_{\text {exp }}\right.$ ) are reported in Table 1. To our knowledge this is the first report of retention indices for the proprietary phase Rtx®-CLPesticides II column.

The compounds reported in Table 1 demonstrate the trapping efficiency of a wide range of pollutants in the environment onto the in-house designed PDMS sampling loop. Thermal desorption of the PDMS sampler directly in the inlet of a GC enabled faster analysis times (no lengthy desorption step) compared to TD using a commercial thermal desorber system (TDS). Furthermore, liquid nitrogen and cryo-focussing are not required as is the case when using a commercial TDS. Enhanced sensitivity is achieved by thermal desorption compared to liquid injection of microlitres of a solvent extract. Although the PDMS sampling loop is reusable, its low cost (0.74 USD) permits its use as a disposable sampler, thereby offering an appealing alternative to SBSE (a comparison of the performance of the PDMS loop to that of SBSE is reported elsewhere [35]). A disposable sampler eliminates compound carryover when doing multiple extractions. The sampler is easy to make and easy to use.

Table 1. Selected compounds detected during an untargeted screening analysis of surface water from Rietvlei Nature Reserve and Albasini Dam using an in-house developed PDMS sampling loop with TD-GC×GC-TOFMS.

\begin{tabular}{|c|c|c|c|c|c|c|c|c|}
\hline $\begin{array}{l}\text { Compound } \\
\text { (mass spectral } \\
\text { similarity }{ }^{1} \geq 80 \% \text { ) }\end{array}$ & $\begin{array}{l}\text { Commentsl } \\
\text { Uses }\end{array}$ & $\begin{array}{l}\text { Classified } \\
\text { EDC }^{2}\end{array}$ & CAS & Formula & $\begin{array}{l}{ }^{1} \mathrm{D} \mathrm{RT}^{3} \\
\text { (s) }\end{array}$ & $\begin{array}{l}{ }^{2} \mathrm{D} \mathrm{RT}^{4} \\
\text { (s) }\end{array}$ & Site detected & $\begin{array}{l}{ }^{1} \mathrm{D} \mathbf{R I}_{\exp } \\
\text { Rtx®- } \\
\text { CLPesticides II }\end{array}$ \\
\hline 1-Phthalanone & Pesticide & No & $87-41-2$ & $\mathrm{C}_{8} \mathrm{H}_{6} \mathrm{O}_{2}$ & 684 & 1.09 & Rietvlei Nature Reserve & 1613 \\
\hline Di-iso-butyl-phthalate & Phthalate & Yes & $84-69-5$ & $\mathrm{C}_{16} \mathrm{H}_{22} \mathrm{O}_{4}$ & 987 & 0.92 & $\begin{array}{l}\text { Rietvlei Nature Reserve } \\
\text { Albasini Dam }\end{array}$ & 2120 \\
\hline Di-nonyl-phthalate & Phthalates & No & $84-76-4$ & $\mathrm{C}_{26} \mathrm{H}_{42} \mathrm{O}_{4}$ & 1443 & 1.04 & Rietvlei Nature Reserve & 2884 \\
\hline $\begin{array}{l}\text { 2-Propanol, 1-chloro- } \\
\text {, phosphate (3:1) } \\
\text { (TCPP) }\end{array}$ & Flame retardant & Yes & $13674-84-5$ & $\begin{array}{l}\mathrm{C}_{9} \mathrm{H}_{18} \mathrm{Cl}_{3} \mathrm{O}_{4} \\
\mathrm{P}\end{array}$ & 975 & 1.02 & Rietvlei Nature Reserve & 2100 \\
\hline Octinoxate & Ultraviolet filter & Yes & $5466-77-3$ & $\mathrm{C}_{18} \mathrm{H}_{26} \mathrm{O}_{3}$ & 1215 & 1.05 & $\begin{array}{l}\text { Rietvlei Nature Reserve } \\
\text { Albasini Dam }\end{array}$ & 2502 \\
\hline Cashmeran & $\begin{array}{l}\text { Synthetic musk } \\
\text { fragrance }\end{array}$ & Yes & $33704-61-9$ & $\mathrm{C}_{14} \mathrm{H}_{22} \mathrm{O}$ & 729 & 0.97 & Rietvlei Nature Reserve & 1689 \\
\hline Acenaphthene & PAH & No & $83-32-9$ & $\mathrm{C}_{12} \mathrm{H}_{10}$ & 2025 & 2.19 & $\begin{array}{l}\text { Rietvlei Nature Reserve } \\
\text { Albasini Dam }\end{array}$ & 3858 \\
\hline
\end{tabular}




\begin{tabular}{|c|c|c|c|c|c|c|c|c|}
\hline Acetamide & $\begin{array}{l}\text { Plastics and as a } \\
\text { solvent }\end{array}$ & No & $60-35-5$ & $\mathrm{C}_{2} \mathrm{H}_{5} \mathrm{NO}$ & 162 & 0.8 & Rietvlei Nature Reserve & 739 \\
\hline Acetochlor & Pesticide & Yes & $34256-82-1$ & $\mathrm{C}_{14} \mathrm{H}_{20} \mathrm{CINO}$ & 1005 & 1.02 & $\begin{array}{l}\text { Rietvlei Nature Reserve } \\
\text { Albasini Dam }\end{array}$ & 2151 \\
\hline $\begin{array}{l}\text { Acetic acid ethenyl } \\
\text { ester }\end{array}$ & Polymer plastics & Yes & $108-05-4$ & $\mathrm{C}_{4} \mathrm{H}_{6} \mathrm{O}_{2}$ & 321 & 0.52 & Albasini Dam & 1006 \\
\hline Acridine & Dyes & Yes & $260-94-6$ & $\mathrm{C}_{13} \mathrm{H}_{9} \mathrm{~N}$ & 960 & 1.34 & Rietvlei Nature Reserve & 2075 \\
\hline Anthracene & PAH & Yes & $120-12-7$ & $\mathrm{C}_{14} \mathrm{H}_{10}$ & 942 & 1.31 & Rietvlei Nature Reserve & 2045 \\
\hline Avobenzone & $\begin{array}{l}\text { Personal care } \\
\text { product (PCP) } \\
\text { sunscreen }\end{array}$ & Yes & 70356-09-1 & $\mathrm{C}_{20} \mathrm{H}_{22} \mathrm{O}_{3}$ & 1455 & 1.3 & Albasini Dam & 2904 \\
\hline Benzene & $\begin{array}{l}\text { Manufacturing of } \\
\text { other chemicals }\end{array}$ & Yes & $71-43-2$ & $\mathrm{C}_{6} \mathrm{H}_{6}$ & 2052 & 0.51 & $\begin{array}{l}\text { Rietvlei Nature Reserve } \\
\text { Albasini Dam }\end{array}$ & 3903 \\
\hline $\begin{array}{l}\text { Benzene, 1,2- } \\
\text { dichloro- }\end{array}$ & $\begin{array}{l}\text { Antimicrobial/ } \\
\text { Pesticide } \\
\text { ingredient }\end{array}$ & Yes & $95-50-1$ & $\mathrm{C}_{6} \mathrm{H}_{4} \mathrm{Cl}_{2}$ & 312 & 2.62 & Rietvlei Nature Reserve & 990 \\
\hline $\begin{array}{l}\text { Benzene, 1,3- } \\
\text { dichloro- }\end{array}$ & $\begin{array}{l}\text { Pesticide } \\
\text { ingredient }\end{array}$ & Yes & $541-73-1$ & $\mathrm{C}_{6} \mathrm{H}_{4} \mathrm{Cl}_{2}$ & 282 & 1.0 & Rietvlei Nature Reserve & 940 \\
\hline Benzophenone & Sunscreen agent & Yes & $119-61-9$ & $\mathrm{C}_{13} \mathrm{H}_{10} \mathrm{O}$ & 843 & 1.14 & $\begin{array}{l}\text { Rietvlei Nature Reserve } \\
\text { Albasini Dam }\end{array}$ & 1879 \\
\hline Benzyl Benzoate & Pharmaceutical & No & $120-51-4$ & $\mathrm{C}_{14} \mathrm{H}_{12} \mathrm{O}_{2}$ & 924 & 1.13 & Rietvlei Nature Reserve & 2015 \\
\hline $\begin{array}{l}\text { Benzyl butyl } \\
\text { phthalate }\end{array}$ & Phthalate & Yes & $85-68-7$ & $\mathrm{C}_{19} \mathrm{H}_{20} \mathrm{O}_{4}$ & 1263 & 1.16 & $\begin{array}{l}\text { Rietvlei Nature Reserve } \\
\text { Albasini Dam }\end{array}$ & 2583 \\
\hline Biphenyl & $\begin{array}{l}\text { Organic } \\
\text { syntheses, etc. }\end{array}$ & Yes & $92-52-4$ & $\mathrm{C}_{12} \mathrm{H}_{10}$ & 1674 & 2.06 & $\begin{array}{l}\text { Rietvlei Nature Reserve } \\
\text { Albasini Dam }\end{array}$ & 3271 \\
\hline Butanenitrile & $\begin{array}{l}\text { Precursor to the } \\
\text { poultry drug } \\
\text { amprolium }\end{array}$ & No & $109-74-0$ & $\mathrm{C}_{4} \mathrm{H}_{7} \mathrm{~N}$ & 87 & 2.12 & Albasini Dam & 614 \\
\hline Caffeine & $\begin{array}{l}\text { Stimulant/ } \\
\text { Pharmaceutical }\end{array}$ & Yes & $58-08-2$ & $\mathrm{C}_{8} \mathrm{H}_{10} \mathrm{~N}_{4} \mathrm{O}_{2}$ & 1020 & 1.23 & $\begin{array}{l}\text { Rietvlei Nature Reserve } \\
\text { Albasini Dam }\end{array}$ & 2176 \\
\hline Caprolactam & $\begin{array}{l}\text { Manufacture of } \\
\text { Nylon-6 }\end{array}$ & No & $105-60-2$ & $\mathrm{C}_{6} \mathrm{H}_{11} \mathrm{NO}$ & 600 & 1.1 & Rietvlei Nature Reserve & 1473 \\
\hline Clofenvinfos & $\begin{array}{l}\text { Insecticide and an } \\
\text { acaricide }\end{array}$ & Yes & $470-90-6$ & $\begin{array}{l}\mathrm{C}_{12} \mathrm{H}_{14} \mathrm{Cl}_{3} \mathrm{O}_{4} \\
\mathrm{P}\end{array}$ & 1122 & 1.21 & Rietvlei Nature Reserve & 2347 \\
\hline Galaxolide & $\begin{array}{l}\text { Personal care } \\
\text { product }\end{array}$ & Yes & $1222-05-5$ & $\mathrm{C}_{18} \mathrm{H}_{26} \mathrm{O}$ & 951 & 1.03 & Rietvlei Nature Reserve & 2060 \\
\hline Diamyl phthalate & Phthalate & Yes & $131-18-0$ & $\mathrm{C}_{18} \mathrm{H}_{26} \mathrm{O}_{4}$ & 1140 & 1.01 & Albasini Dam & 2377 \\
\hline Diazinone & Insecticide & Yes & $333-41-5$ & $\begin{array}{l}\mathrm{C}_{12} \mathrm{H}_{21} \mathrm{~N}_{2} \mathrm{O}_{3} \\
\text { PS }\end{array}$ & 933 & 1.04 & $\begin{array}{l}\text { Rietvlei Nature Reserve } \\
\text { Albasini Dam }\end{array}$ & 2030 \\
\hline Dibenzofuran & Insecticide & No & $132-64-9$ & $\mathrm{C}_{12} \mathrm{H}_{8} \mathrm{O}$ & 741 & 1.14 & $\begin{array}{l}\text { Rietvlei Nature Reserve } \\
\text { Albasini Dam }\end{array}$ & 1709 \\
\hline Dibenzothiophene & $\begin{array}{l}\text { Cosmetic } \\
\text { ingredient }\end{array}$ & Yes & $132-65-0$ & $\mathrm{C}_{12} \mathrm{H}_{8} \mathrm{~S}$ & 918 & 1.25 & Rietvlei Nature Reserve & 2005 \\
\hline Dibutyl phthalate & Phthalate & Yes & $84-74-2$ & $\mathrm{C}_{16} \mathrm{H}_{22} \mathrm{O}_{4}$ & 1041 & 0.98 & $\begin{array}{l}\text { Rietvlei Nature Reserve } \\
\text { Albasini Dam }\end{array}$ & 2211 \\
\hline Diethyl Phthalate & Phthalate & Yes & $84-66-2$ & $\mathrm{C}_{12} \mathrm{H}_{14} \mathrm{O}_{4}$ & 810 & 1.05 & $\begin{array}{l}\text { Rietvlei Nature Reserve } \\
\text { Albasini Dam }\end{array}$ & 1824 \\
\hline $\begin{array}{l}\text { Diethylene glycol } \\
\text { dibenzoate }\end{array}$ & Plasticizer & No & $120-55-8$ & $\mathrm{C}_{18} \mathrm{H}_{18} \mathrm{O}_{5}$ & 1329 & 1.25 & $\begin{array}{l}\text { Rietvlei Nature Reserve } \\
\text { Albasini Dam }\end{array}$ & 2693 \\
\hline Diisooctyl phthalate & Phthalate & No & $131-20-4$ & $\mathrm{C}_{24} \mathrm{H}_{38} \mathrm{O}_{4}$ & 1314 & 0.99 & $\begin{array}{l}\text { Rietvlei Nature Reserve } \\
\text { Albasini Dam }\end{array}$ & 2668 \\
\hline Doconexent & Pharmaceutical & No & $6217-54-5$ & $\mathrm{C}_{22} \mathrm{H}_{32} \mathrm{O}_{2}$ & 1002 & 0.96 & Rietvlei Nature Reserve & 2146 \\
\hline Fenazaquin & Pesticide & No & $120928-09-8$ & $\mathrm{C}_{20} \mathrm{H}_{22} \mathrm{~N}_{2} \mathrm{O}$ & 576 & 0.96 & Rietvlei Nature Reserve & 1432 \\
\hline Fluoranthene & PAH & Yes & $206-44-0$ & $\mathrm{C}_{16} \mathrm{H}_{10}$ & 1110 & 1.35 & $\begin{array}{l}\text { Rietvlei Nature Reserve } \\
\text { Albasini Dam }\end{array}$ & 2326 \\
\hline Fluorene & $\mathrm{PAH}$ & Yes & $86-73-7$ & $\mathrm{C}_{13} \mathrm{H}_{10}$ & 789 & 1.18 & $\begin{array}{l}\text { Rietvlei Nature Reserve } \\
\text { Albasini Dam }\end{array}$ & 1789 \\
\hline Glycidol & $\begin{array}{l}\text { Organic synthesis/ } \\
\text { Polymer plastic }\end{array}$ & Yes & $556-52-5$ & $\mathrm{C}_{3} \mathrm{H}_{6} \mathrm{O}_{2}$ & 195 & 0.79 & Albasini Dam & 795 \\
\hline $\begin{array}{l}\text { di-(2-ethylhexyl) } \\
\text { adipate (DEHA) }\end{array}$ & Plasticiser & Yes & $103-23-1$ & $\mathrm{C}_{22} \mathrm{H}_{42} \mathrm{O}_{4}$ & 1227 & 0.88 & $\begin{array}{l}\text { Rietvlei Nature Reserve } \\
\text { Albasini Dam }\end{array}$ & 2522 \\
\hline Metolachlor & Herbicide & Yes & $1438-62-6$ & $\begin{array}{l}\mathrm{C}_{15} \mathrm{H}_{22} \mathrm{CINO} \\
2\end{array}$ & 1062 & 1.09 & Rietvlei Nature Reserve & 2246 \\
\hline Musk ketone & $\mathrm{PCP} /$ fragrance & Yes & 81-14-1 & $\mathrm{C}_{14} \mathrm{H}_{18} \mathrm{~N}_{2} \mathrm{O}_{5}$ & 840 & 1.07 & Rietvlei Nature Reserve & 1874 \\
\hline Naphthalene & $\mathrm{PAH}$ & Yes & $91-20-3$ & $\mathrm{C}_{10} \mathrm{H}_{8}$ & 468 & 1.1 & $\begin{array}{l}\text { Rietvlei Nature Reserve } \\
\text { Albasini Dam }\end{array}$ & 1252 \\
\hline Octicizer & $\begin{array}{l}\text { Pesticide / } \\
\text { Insecticide }\end{array}$ & No & $1241-94-7$ & $\mathrm{C}_{20} \mathrm{H}_{27} \mathrm{O}_{4} \mathrm{P}$ & 1263 & 1.07 & $\begin{array}{l}\text { Rietvlei Nature Reserve } \\
\text { Albasini Dam }\end{array}$ & 2583 \\
\hline Octocrylene & $\mathrm{PCP} /$ sunscreen & No & $6197-30-4$ & $\mathrm{C}_{24} \mathrm{H}_{27} \mathrm{NO}_{2}$ & 1407 & 1.13 & $\begin{array}{l}\text { Rietvlei Nature Reserve } \\
\text { Albasini Dam }\end{array}$ & 2824 \\
\hline Oxybenzone & $\begin{array}{l}\text { Personal Care } \\
\text { Product/ } \\
\text { Sunscreen }\end{array}$ & Yes & $131-57-7$ & $\mathrm{C}_{14} \mathrm{H}_{12} \mathrm{O}_{3}$ & 1098 & 1.2 & $\begin{array}{l}\text { Rietvlei Nature Reserve } \\
\text { Albasini Dam }\end{array}$ & 2306 \\
\hline Phenanthrene & PAH & Yes & $85-01-8$ & $\mathrm{C}_{14} \mathrm{H}_{10}$ & 936 & 1.26 & Rietvlei Nature Reserve & 2035 \\
\hline
\end{tabular}




\begin{tabular}{|c|c|c|c|c|c|c|c|c|}
\hline \multirow[b]{2}{*}{ 4-tert-Octylphenol } & \multirow[b]{2}{*}{$\begin{array}{l}\text { Phthalates/ } \\
\text { surfactant }\end{array}$} & \multirow[b]{2}{*}{ Yes } & \multirow[b]{2}{*}{$140-66-9$} & \multirow[b]{2}{*}{$\mathrm{C}_{14} \mathrm{H}_{22} \mathrm{O}$} & \multirow[b]{2}{*}{840} & \multirow[b]{2}{*}{0.97} & \multicolumn{2}{|l|}{ Albasini Dam } \\
\hline & & & & & & & Rietvlei Nature Reserve & 1874 \\
\hline 4-tert-Amylphenol & Pesticide & Yes & $80-46-6$ & $\mathrm{C}_{11} \mathrm{H}_{16} \mathrm{O}$ & 852 & 1.0 & $\begin{array}{l}\text { Rietvlei Nature Reserve } \\
\text { Albasini Dam }\end{array}$ & 1894 \\
\hline Bisphenol A & $\begin{array}{l}\text { Phthalates/ } \\
\text { plasticizer/ BPA }\end{array}$ & Yes & $80-05-7$ & $\mathrm{C}_{15} \mathrm{H}_{16} \mathrm{O}_{2}$ & 1176 & 1.34 & $\begin{array}{l}\text { Rietvlei Nature Reserve } \\
\text { Albasini Dam }\end{array}$ & 2437 \\
\hline Phenylephrine & Pharmaceutical & No & $59-42-7$ & $\mathrm{C}_{9} \mathrm{H}_{13} \mathrm{NO}_{2}$ & 117 & 0.85 & Rietvlei Nature Reserve & 664 \\
\hline Piperonyl butoxide & Pesticide & Yes & $51-03-6$ & $\mathrm{C}_{19} \mathrm{H}_{30} \mathrm{O}_{5}$ & 1257 & 1.17 & Rietvlei Nature Reserve & 2573 \\
\hline Pyrene & $\mathrm{PAH}$ & Yes & $129-00-0$ & $\mathrm{C}_{16} \mathrm{H}_{10}$ & 1146 & 1.4 & Rietvlei Nature Reserve & 2387 \\
\hline Retene & $\mathrm{PAH}$ & Yes & $483-65-8$ & $\mathrm{C}_{18} \mathrm{H}_{18}$ & 1212 & 1.27 & Rietvlei Nature Reserve & 2497 \\
\hline Spiroxamine & Fungicide & No & $118134-30-8$ & $\mathrm{C}_{18} \mathrm{H}_{35} \mathrm{NO}_{2}$ & 942 & 0.92 & $\begin{array}{l}\text { Rietvlei Nature Reserve } \\
\text { Albasini Dam }\end{array}$ & 2045 \\
\hline Styrene & Plastics and resins & Yes & $100-42-5$ & $\mathrm{C}_{8} \mathrm{H}_{8}$ & 165 & 0.93 & Albasini Dam & 744 \\
\hline Sulfotep & Pesticide & No & $3689-24-5$ & $\begin{array}{l}\mathrm{C}_{8} \mathrm{H}_{20} \mathrm{O}_{5} \mathrm{P}_{2} \\
\mathrm{~S}_{2}\end{array}$ & 879 & 1.03 & Rietvlei Nature Reserve & 1940 \\
\hline Terbuthylazine & Herbicide & No & $171199-36-3$ & $\mathrm{C}_{9} \mathrm{H}_{16} \mathrm{ClN}_{5}$ & 936 & 1.1 & Rietvlei Nature Reserve & 2035 \\
\hline Triazophos & Pesticide & No & $24017-47-8$ & $\begin{array}{l}\mathrm{C}_{12} \mathrm{H}_{16} \mathrm{~N}_{3} \mathrm{O}_{3} \\
\mathrm{PS}\end{array}$ & 1269 & 1.31 & Rietvlei Nature Reserve & 2593 \\
\hline Tributyl phosphate & $\begin{array}{l}\text { Extractant and a } \\
\text { plasticizer (TBP) }\end{array}$ & Yes & $126-73-8$ & $\mathrm{C}_{12} \mathrm{H}_{27} \mathrm{O}_{4} \mathrm{P}$ & 837 & 0.85 & $\begin{array}{l}\text { Rietvlei Nature Reserve } \\
\text { Albasini Dam }\end{array}$ & 1869 \\
\hline Triclosan & Antiseptics/ PCP & Yes & $3380-34-5$ & $\mathrm{C}_{12} \mathrm{H}_{7} \mathrm{Cl}_{3} \mathrm{O}_{2}$ & 1119 & 1.25 & Rietvlei Nature Reserve & 2341 \\
\hline Tuaminoheptane & Pharmaceutical & No & $123-82-0$ & $\mathrm{C}_{7} \mathrm{H}_{17} \mathrm{~N}$ & 135 & 2.93 & Rietvlei Nature Reserve & 694 \\
\hline $\begin{array}{l}{ }^{1} \text { Spectral } \\
{ }^{2} \text { EDCs cla } \\
\text { TEDX, Th } \\
{ }^{3} \text { First dime } \\
{ }^{4} \text { Second d }\end{array}$ & $\begin{array}{l}\text { atch quality (NIST14 } \\
\text { sified using the EDC } \\
\text { Endocrine Disruptior } \\
\text { sion retention time } \\
\text { hension retention tim }\end{array}$ & $\begin{array}{l}4 \text { libre } \\
\text { daté } \\
\text { n Ex }\end{array}$ & $\begin{array}{l}\text { tative identifi } \\
\text { eated by Dr } \\
{[36,37] \text {. }}\end{array}$ & $\begin{array}{l}\text { ation } \\
\text { Montes-G }\end{array}$ & & & rbel, University of $\mathrm{Ca}$ & \\
\hline
\end{tabular}

\subsection{Targeted analysis}

The results from the untargeted screening were used to select 12 reference standards for targeted analysis. Experimental linear retention indices for the analytical standards determined by GCXGC-TOFMS and comparison thereof to polar and standard non-polar column phases are given in Table 2. Retention indices for the proprietary phase Rtx®-CLPesticides II column could not be found in the literature, therefore reporting it herein may prove useful to others.

The analytes selected represent a broad range (pesticides, plasticiser, fragrance, personal care products, pharmaceuticals) of heterogeneous chemical compounds. The goal of selecting these compounds was to simulate the variation in chemical characteristics and classes one would expect when detecting EDCs and antiretroviral compounds in real world samples.

Table 2. The experimental and literature linear retention indices of the target compounds (certified reference standards) using an in-house developed PDMS sampling loop with TD-GC×GC-TOFMS.

\begin{tabular}{|c|c|c|c|c|}
\hline \multirow[t]{2}{*}{ Compound } & \multirow[t]{2}{*}{${ }^{1} \mathrm{DRT}^{1}(\mathrm{~s})$} & \multirow{2}{*}{$\begin{array}{c}{ }^{1} \mathrm{D} \mathrm{RI}_{\exp } \\
\text { Rtx }{ }^{\circledR}- \\
\text { CLPesticides } \\
\text { II }\end{array}$} & \multicolumn{2}{|c|}{${ }^{1} \mathrm{D} \mathrm{RI}_{\text {Lit }}$ NIST14 } \\
\hline & & & Polar & $\begin{array}{l}\text { Standard Non- } \\
\text { polar }\end{array}$ \\
\hline 4-tert-Amylphenol & 627 & 1518 & Not available & 1433 \\
\hline Acetaminophen & 924 & 2015 & Not available & 1650 \\
\hline Atrazine & 924 & 2015 & 2762 & 1712 \\
\hline Lindane & 933 & 2030 & Not available & 1728 \\
\hline Terbuthylazine & 936 & 2035 & 2664 & 1755 \\
\hline Caffeine & 1020 & 2176 & Not available & 1800 \\
\hline Terbutryn & 1035 & 2201 & 2793 & 1912 \\
\hline Chlorpyrifos & 1059 & 2241 & Not available & 1957 \\
\hline Metolachlor & 1062 & 2246 & Not available & 2054 \\
\hline Musk ketone & 1083 & 2281 & Not available & 1925 \\
\hline
\end{tabular}


${ }^{1}$ First dimension retention time

\subsection{Method performance}

\subsubsection{Linearity}

The performance of both methods was evaluated by plotting multi-level calibration curves (matrix matched) using at least five concentration levels of the target analytes. The linearity of the two matrix matched calibrations using the PDMS sampling loop with direct GC inlet liner TD-GC ×GC-TOFMS and LVI with UHPLC-MS/MS is given in Table 3. The linear regression fit $\left(R^{2}\right)$ for all cases (excluding efavirenz) was greater than 0.956 and 0.980 for $\mathrm{GC}$ and LC analysis, respectively. In the case of efavirenz standards added at concentrations greater than $5 \mathrm{ng} / \mathrm{l}$ were outside of the linear range. A new multi-level calibration set within the linear range for efavirenz was not prepared, because the water samples were by that stage depleted. Therefore, repeat extractions and multi-level quantification were not possible for efavirenz and thus efavirenz is reported as semi-quantitative.

\subsubsection{Limit of detection (LOD) and limit of quantification (LOQ)}

Table 3 gives the LODs and LOQs of the PDMS sampling loop with direct GC inlet liner TD-GC $\times$ GC-TOFMS and the LVI with UHPLC-MS/MS methods. The LODs and LOQs for the sorptive extraction technique with GC analysis ranged from $0.0010 \mathrm{ng} / \mathrm{l}$ for metolachlor to $0.098 \mathrm{ng} / \mathrm{l}$ for 4-tert-Amylphenol and 0.0030 (metolachlor) to $0.33 \mathrm{ng} / \mathrm{l}$ (4-tert-amylphenol), respectively. LODs and LOQs for LVI-LC ranged from 1.97 for atrazine to $135 \mathrm{ng} / \mathrm{l}$ for acetaminophen and 6.56 (atrazine) to $449 \mathrm{ng} / \mathrm{l}$ (acetaminophen), respectively. Measurements at ultra-trace levels (ppq to low ppb) of the target analytes are realised for both the GC and LC methods. Although the TD-GC method is more sensitive and detects a larger number of target analytes compared to the LVI-LC method, the LODs and LOQs of both methods are significantly lower than the levels required by the EU directive, WHO (World Health Organisation) guidelines and US EPA regulations for drinking water quality [38-40]. The maximum contaminant level goal (MCL) (the level of a contaminant below which there is no known or expected risk to health) set by the EU guidelines for pesticides is $100 \mathrm{ng} / \mathrm{l}$ (total pesticides $200 \mathrm{ng} / \mathrm{l})$. The $\mathrm{MCL}$ set by the $\mathrm{WHO}$ is $100 \mu \mathrm{g} / \mathrm{l}$ for atrazine, $30 \mu \mathrm{g} / \mathrm{l}$ for chlorpyrifos, $2 \mu \mathrm{g} / \mathrm{l}$ for lindane, $10 \mu \mathrm{g} / \mathrm{l}$ for metolachlor and $7 \mu \mathrm{g} / \mathrm{l}$ for terbuthylazine. The US EPA regulations set the MCL for atrazine at $0.003 \mathrm{mg} / \mathrm{l}$ and lindane at $0.0002 \mathrm{mg} / \mathrm{l}$ [38-40].

Table 3. Matrix matched calibration: Linearity, LODs and LOQs of the TD-GC×GC-TOFMS and LVI-UHPLCMS/MS methods.

\begin{tabular}{|c|c|c|c|c|c|c|c|}
\hline \multirow[t]{2}{*}{ Compound } & \multirow{2}{*}{$\begin{array}{c}\text { Quantification } \\
\text { Ion } \\
\mathrm{m} / \mathrm{z}\end{array}$} & \multicolumn{4}{|c|}{ Linearity } & \multirow{2}{*}{$\begin{array}{l}\text { LODs }^{2} \\
\text { (ng/l) }\end{array}$} & \multirow{2}{*}{$\begin{array}{c}\mathrm{LOQs}^{3} \\
\text { (ng/l) }\end{array}$} \\
\hline & & $\begin{array}{c}\text { Range } \\
\text { (ng/l) }\end{array}$ & $\begin{array}{l}\text { Number } \\
\text { of points }\end{array}$ & $\begin{array}{c}\text { Regression } \\
\text { Equation }^{1} \\
\end{array}$ & $\mathbf{R}^{2}$ & & \\
\hline
\end{tabular}




\begin{tabular}{|c|c|c|c|c|c|c|c|}
\hline \multicolumn{8}{|c|}{ PDMS sampling loops in inlet liner TD-GCXGC-TOFMS } \\
\hline 4-tert-Amylphenol & 135 & $0-40$ & 6 & $y=14483 x+7650.6$ & 0.970 & 0.098 & 0.33 \\
\hline Atrazine & 200 & $0-40$ & 6 & $y=22074 x+4667.5$ & 0.969 & 0.076 & 0.25 \\
\hline Lindane & 181 & $0-40$ & 8 & $y=111369 x+4865.9$ & 0.992 & 0.0088 & 0.029 \\
\hline Terbuthylazine & 173 & $0-40$ & 5 & $y=35518 x+19749$ & 0.956 & 0.0017 & 0.0055 \\
\hline Caffeine & 194 & $0-40$ & 5 & $y=46921 x+16978$ & 0.970 & 0.026 & 0.085 \\
\hline Terbutryn & 226 & $0-40$ & 6 & $y=52171 x+4323.1$ & 0.998 & 0.012 & 0.039 \\
\hline Chlorpyrifos & 97 & $0-40$ & 6 & $y=369184 x-6267.9$ & 0.995 & 0.036 & 0.12 \\
\hline Metolachlor & 162 & $0-40$ & 6 & $y=196658 x+52174$ & 0.957 & 0.0010 & 0.0030 \\
\hline Musk ketone & 279 & $0-40$ & 8 & $y=47780 x+50.037$ & 0.997 & 0.0013 & 0.0043 \\
\hline Efavirenz $^{4}$ & 246 & 5 & 1 & - & - & - & - \\
\hline \multicolumn{8}{|c|}{ LVI-UHPLC-MS/MS } \\
\hline Acetaminophen & 152.071 & $\begin{array}{c}0- \\
10000\end{array}$ & $\overline{5}$ & $y=0.0843 x+48.871$ & 0.980 & 135 & 449 \\
\hline Atrazine & 216.101 & $\begin{array}{c}0- \\
10000\end{array}$ & 6 & $y=1.3263 x+431.19$ & 0.985 & 1.97 & 6.56 \\
\hline Nevirapine & 267.124 & $\begin{array}{c}0- \\
10000\end{array}$ & 5 & $y=0.1652 x+57.838$ & 0.990 & 44.4 & 148 \\
\hline
\end{tabular}

${ }^{1} y=$ peak area of compound; $x=$ concentration of the compound (ng/l)

${ }^{2} \mathrm{LOD}$ calculated as the concentration which gives a signal-to-noise ratio $(\mathrm{S} / \mathrm{N})$ of 3

${ }^{3} \mathrm{LOQ}$ calculated as the concentration which gives a S/N of 10

${ }^{4}$ Single point calibration. See 3.3.1.

\subsubsection{Accuracy and precision}

Accuracy (\% recovery) and precision (\% relative standard deviation (RSD)) were determined, in triplicate, by spiking de-ionised water at a level of $20 \mathrm{ng} / \mathrm{l}$ for the evaluation of the sorptive sampler GC method. Results are reported elsewhere [35]. In short, for the PDMS loop sorptive sampler thermally desorbed directly in the inlet liner of a GC analyte recoveries ranged from $85 \%$ to $121 \%$ and \% RSD ranged from 6.6 to $14 \%$ (excluding caffeine). Compared to the other target compounds caffeine produced a somewhat higher recovery (152\%) and lower precision (55\% RSD). For the LVI with UHPLC-MS/MS method accuracy (\% recovery) and precision (\% RSD) were determined, in triplicate, by spiking de-ionised water at a level of $2.5 \mu \mathrm{g} / \mathrm{l}$. Recovery for acetaminophen was $109 \pm 6 \%$ with a $5.5 \%$ RSD; for atrazine the recovery was $117 \pm 4 \%$ with a $3.4 \%$ RSD; and for nevirapine the recovery was $112 \pm 13 \%$ with a $12 \%$ RSD.

\subsection{Real world samples}

The PDMS loop sorptive sampler was used here for the first time as a quantitative device for a range of different compound classes. The results for the target analysis using GC $\times G C$ TOFMS for Rietvlei Nature Reserve (sampling done on 15/3/2016) and Albasini Dam (sampling done on 17/8/2015) are given in Table 4. The Rtx ${ }^{\circledR}$-CLPesticides II column gave sufficient separation of the targeted chlorinated pesticides, chlorpyrifos and metolachlor, to enable quantification (Fig. 4). It was found that chlorpyrifos and metolachlor co-eluted on a $30 \mathrm{~m} \times 0.25$ mm ID $\times 0.25 \mu \mathrm{m}$ film thickness $\mathrm{Rxi}^{\circledR}-1 \mathrm{~ms}$ column (results not shown), and therefore a Rtx ${ }^{\circledR}$ CLPesticides II column was used instead.

The target compounds occur at trace levels in surface water from Rietvlei Nature Reserve as sampling was done during a heavy rainfall period. The higher presence of pesticides and personal care products (PCPS) in the surface water from Rietvlei Nature Reserve, located in an urban area, compared to surface water from the Albasini Dam in a rural area, reflects the human impact on the 
environment. The presence of lindane $(0.38 \mathrm{ng} / \mathrm{L})$ at the Otter Bridge sampling site (Rietvlei Nature Reserve) is cause for concern as production and agricultural use of this organochlorine pesticide was banned under the Stockholm Convention on persistent organic pollutants (POPs) (2009) [41]. Of interest is that DDT, which is thought to be a main cause of endocrine disruption in the Limpopo Province [6, 7], and in Rietvlei Nature Reserve [2, 42] (although DDT is not used in the Gauteng Province where Rietvlei Nature Reserve is located), was not detected in any of the surface water analyses. Oestrogenic activity was confirmed in drinking water samples from the Limpopo Province [6]. The compounds responsible for this oestrogenic activity have not yet been identified [6]. However, the range of EDCs detected (Tables 1 and 4) indicates that the reported oestrogenic activity may be due to additive effects, rather than a single chemical. Future monitoring at Rietvlei Nature Reserve and Albasini Dam is thus required as the large range of pollutants detected can increase oestrogenic activity in the water.

Table 4. Target analytes detected (ng/l) in surface water.

\begin{tabular}{|c|c|c|c|c|c|c|c|}
\hline & \multicolumn{6}{|c|}{ Rietvlei Nature Reserve, Gauteng Province, South Africa } & \multirow{3}{*}{$\begin{array}{l}\text { Limpopo } \\
\text { Province, South } \\
\text { Africa }\end{array}$} \\
\hline & \multicolumn{6}{|c|}{ Six sampling sites } & \\
\hline & 1. & 2. & 3. & 4. & 5. & 6. & \\
\hline & STR Fam & $\begin{array}{c}\text { Otter } \\
\text { Bridge }\end{array}$ & $\begin{array}{c}\text { Bird Hide } \\
\text { Stream }\end{array}$ & $\begin{array}{c}\text { Rietvlei } \\
\text { Spruit }\end{array}$ & Marais Dam & $\begin{array}{c}\text { MD } \\
\text { Channel }\end{array}$ & Albasini Dam \\
\hline Target Analyte & (ng/l) & (ng/l) & (ng/l) & (ng/l) & (ng/l) & (ng/l) & (ng/l) \\
\hline
\end{tabular}

EDC: Plasticiser, pesticide, antimicrobial

\begin{tabular}{|c|c|c|c|c|c|c|c|}
\hline $\begin{array}{l}\text { 4-tert-Amylphenol } \\
\text { EDC: Pesticide }\end{array}$ & $<0.098$ & $<0.098$ & 0.99 & 6.7 & $<0.098$ & $<0.098$ & $<0.098$ \\
\hline Atrazine & $<0.076$ & 0.41 & $<0.076$ & $<0.076$ & 0.40 & $<0.076$ & $<0.076$ \\
\hline Lindane & $<0.0088$ & 0.38 & $<0.0088$ & $<0.0088$ & $<0.0088$ & $<0.0088$ & $<0.0088$ \\
\hline Terbuthylazine & $<0.0017$ & 3.8 & $<0.0017$ & 0.86 & 0.37 & $<0.0017$ & $<0.0017$ \\
\hline Terbutryn & $<0.012$ & 0.17 & $<0.012$ & $<0.012$ & 0.16 & $<0.012$ & $<0.012$ \\
\hline Chlorpyrifos & $<0.036$ & 0.24 & $<0.036$ & 0.24 & $<0.036$ & $<0.036$ & 0.14 \\
\hline Metolachlor & $<0.0010$ & 0.19 & $<0.0010$ & 0.54 & 0.32 & 0.36 & $<0.0010$ \\
\hline EDC: Personal Care & uct, Pharn & utical, & tor of hu & pollution & & & \\
\hline $\begin{array}{l}\text { Caffeine } \\
\text { EDC: Fragrance }\end{array}$ & $<0.026$ & 0.80 & 0.73 & $<0.026$ & $<0.026$ & $<0.026$ & $<0.026$ \\
\hline $\begin{array}{l}\text { Musk ketone } \\
\text { Antiretroviral drug }\end{array}$ & 0.039 & 2.4 & 0.066 & 4.0 & 3.6 & 0.43 & $<0.0013$ \\
\hline Efavirenz & n.d. ${ }^{1}$ & $148^{2}$ & n.d. & 0.34 & 76 & 29 & n.d. \\
\hline
\end{tabular}


EDC: Pharmaceutical

\begin{tabular}{|c|c|c|c|c|c|c|c|}
\hline Acetaminophen & $<135$ & $<135$ & $<135$ & $<135$ & $<135$ & $<135$ & $<135$ \\
\hline \multicolumn{8}{|l|}{ EDC: Pesticide } \\
\hline Atrazine & $<1.97$ & $<1.97$ & $<1.97$ & 60.8 & 56.7 & $<1.97$ & $<1.97$ \\
\hline \multicolumn{8}{|l|}{ Antiretroviral drug } \\
\hline Nevirapine & $<44.4$ & <148 (124) & $<44.4$ & <148 (109) & $<44.4$ & 227 & $<44.4$ \\
\hline
\end{tabular}

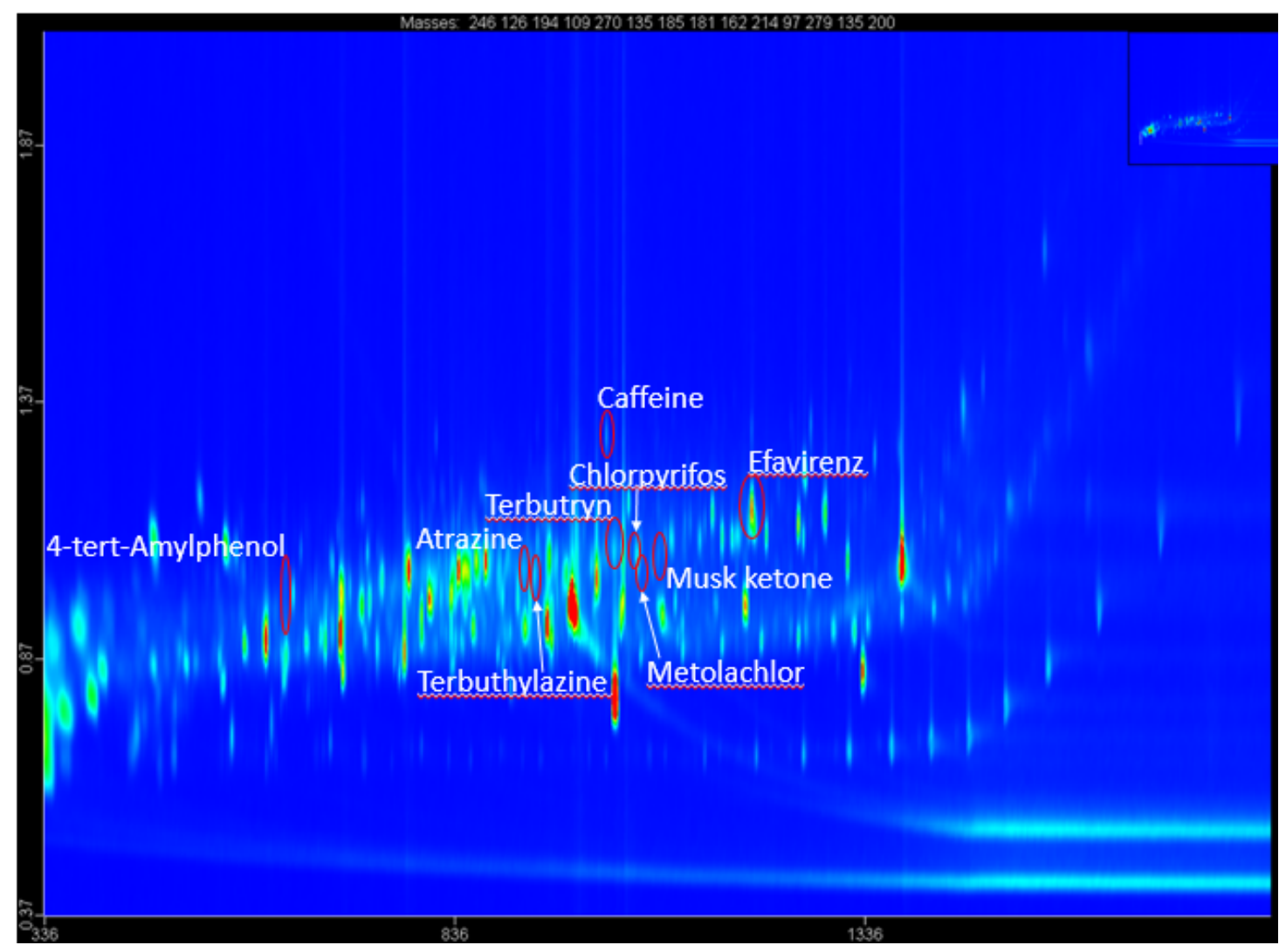

Figure 4. Contour plot of a reconstructed ion chromatogram (RIC) (GC×GC-TOFMS) of surface water collected at site 2 (Otter Bridge) in Rietvlei Nature Reserve. Target analytes detected are indicated. RIC: 246, 126, 194, 109, 270, 135, 181, 185, 162, 214, 97, 279 and $200 \mathrm{~m} / \mathrm{z}$. 
The results for the target analysis using LVI UHPLC-MS/MS for Rietvlei Nature Reserve (sampling date 6/2/2015) and Albasini Dam (sampling date 17/8/2015) are given in Table 4. To our knowledge this is a first report on the use of LVI UHPLC-MS/MS in South Africa. Unequivocal identification of target analytes was attained using retention times, accurate mass and MS/MS fragmentation patterns. LVI-LC was particularly suited for the quantification of nevirapine (Fig. 5.). The emerging EDC, acetaminophen (paracetamol), was not detected. The levels of atrazine detected during February 2015 at sampling sites Rietvlei Spruit and Marais Dam (Rietvlei Nature Reserve) were considerably higher than levels detected during the heavy rainfall period of March 2016 (Table 4). The direct injection of the surface water $(100 \mu \mathrm{l})$, with minimal prior sample treatment, into the LC is an attractive approach as it avoids time consuming sample preparation steps making it ideal for fast and high-throughput analysis, and it reduces the amount of solvent used.

The presence of efavirenz (Fig. 4) at four of the Rietvlei Nature Reserve sampling sites, and of nevirapine (Fig. 5) at three of the six Rietvlei Nature Reserve sampling sites (Table 4), is cause for concern. Efavirenz and nevirapine are antiretroviral (ARVs) drugs used for the treatment of HIV and can be considered emerging pollutants. The concentration levels of the ARVs detected in surface water are higher than that of the EDCs. Considering that inhabitants of informal settlements in South Africa use untreated water from rivers and dams for drinking, cooking and cleaning environmental monitoring of South African surface water should also include ARVs as priority pollutants. The number of target compounds selected was to mainly demonstrate the performance of the two complementary methods. This target list may easily be expanded.

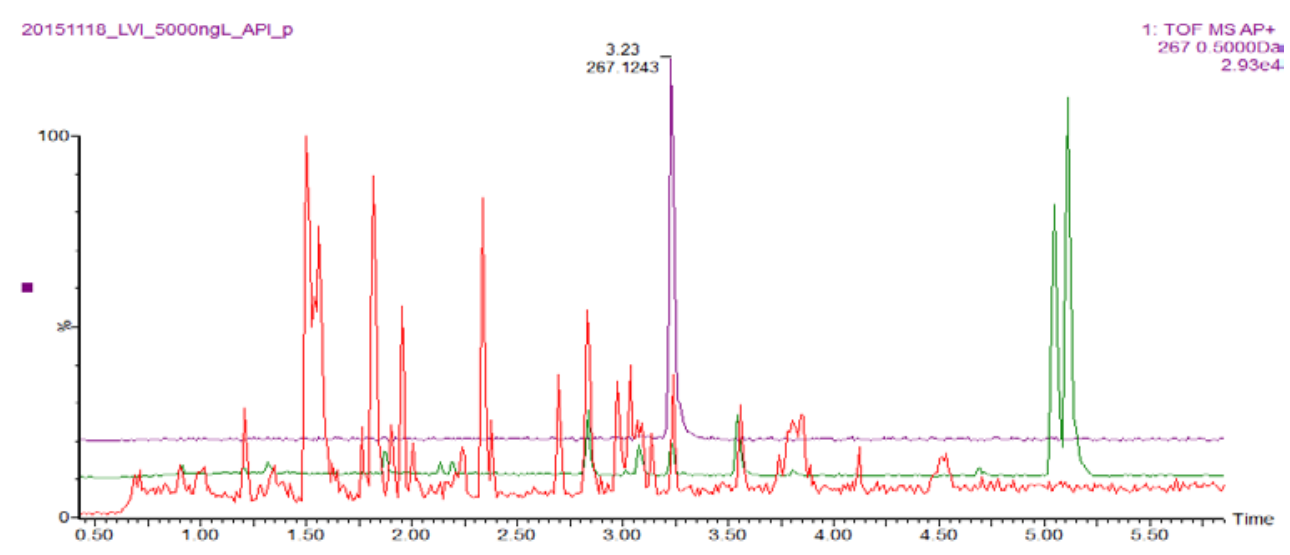

Figure 5. LVI UHPLC base peak ion (BPI) chromatogram of surface water collected at site 4 (Rietvlei Spruit (spring)) in Rietvlei Nature Reserve (bottom trace); LVI UHPLC BPI chromatogram of a $5000 \mathrm{ng} / \mathrm{l}$ mixed reference standard (middle trace); LVI UHPLC RIC of $267.124 \mathrm{~m} / \mathrm{z}$ (nevirapine) from Rietvlei Spruit (top trace); APCI positive mode (QTOF-MS/MS). Peak labels show retention time (minutes); $(\mathrm{M}+\mathrm{H})^{+}$mass $(\mathrm{Da})$. 


\section{Conclusion}

A combination of GC×GC-TOFMS and UHPLC-QTOF-MS/MS for the multi-residue analysis of surface water from South Africa was reported. An in-house developed PDMS sorptive sampling loop with direct thermal desorption in the inlet liner of a GC of a GC×GC-TOFMS, and LVI with UHPLC-MS/MS were used as complementary methods for the detection of EDCs, potential EDCs and antiretroviral drugs in surface water at ultra-trace levels. LODs ranged from ppq to ppt levels. The PDMS sampling loop, a low cost alternative to SBSE, costs less than one US dollar, is easy to make and to use, is disposable and permits solvent free extraction. The loop was thermally desorbed directly in the inlet liner of the GC, thus reducing sample introduction time and cryo-focussing was not required. The direct injection of surface water $(100 \mu \mathrm{l})$, with negligible prior sample treatment, into an LC is an attractive approach as it avoids time consuming sample preparation steps and reduces the amount of solvent used. The simplicity of the two complimentary methods makes it highly suitable for implementation in environmental monitoring programmes.

\section{Acknowledgements}

We wish to thank Tim Wood (Protechnik Laboratories, South Africa) for kind donation of efavirenz and nevirapine standards, Riana Bornman and Natalie Aneck-Hahn for providing a number of water samples, Riaan Marais for allowing us access to the water in Rietvlei Nature Reserve, David Masemula for assembling the PDMS loops, Jack Cochran for generous donations of GC columns and supplies, Peter Gorst-Allman from LECO Africa (Pty) Ltd. for assisting with the software and the National Research Foundation (NRF) for financial support. 


\section{References}

[1] B. Genthe, W.J. Le Roux, K. Schachtschneider, P.J. Oberholster, N.H. Aneck-Hahn, J. Chamier, Health risk implications from simultaneous exposure to multiple environmental contaminants, Ecotoxicol. Environ. Saf., 93 (2013) 171-179.

[2] N.H. Aneck-Hahn, M.S. Bornman, C. De Jager, Preliminary assessment of oestrogenic activity in water sources in Rietvlei Nature Reserve, Gauteng, South Africa, Afr. J. Aquat. Sci., 33 (2008) 249254.

[3] R. Jeannot, H. Sabik, E. Sauvard, T. Dagnac, K. Dohrendorf, Determination of endocrine-disrupting compounds in environmental samples using gas and liquid chromatography with mass spectrometry, J. Chromatogr. A, 974 (2002) 143-159.

[4] WHO UNEP, State of the Science of Endocrine Disrupting Chemicals 2012, Summary for Decision Makers. http://www.who.int/ceh/publications/endocrine/en/, 2012 (accessed 16.09.30)

[5] N. Aneck-Hahn, C. De Jager, I. Barnhoorn, M. Bornman, Endocrine disruptors and health: should South Africa be concerned? http://www.ewisa.co.za/literature/files/216\%20Aneck_Hahn.pdf, 2016 (accessed 16.02.15)

[6] N.H. Aneck-Hahn, M. Bornman, C. De Jager, Oestrogenic activity in drinking waters from a rural area in the Waterberg District, Limpopo Province, South Africa, Water SA, 35 (2009) 245-251.

[7] N.H. Aneck-Hahn, G.W. Schulenburg, M.S. Bornman, P. Farias, C. De Jager, Impaired semen quality associated with environmental DDT exposure in young men living in a malaria area in the Province, South Africa, J. Androl., 28 (2007) 423-434.

[8] C. De Jager, J. Myburgh, B. van der Burg, J. Lemmen, M. Bornman, Estrogenic contamination of South African river waters: a pilot study, American Waterworks Water Association, April, (2002) 1820.

[9] A.M. Comerton, R.C. Andrews, D.M. Bagley, Practical overview of analytical methods for endocrine-disrupting compounds, pharmaceuticals and personal care products in water and wastewater, Philos Trans A Math Phys Eng Sci, 367 (2009) 3923-3939.

[10] J. Annamalai, V. Namasivayam, Endocrine disrupting chemicals in the atmosphere: Their effects on humans and wildlife, Environ. Int., 76 (2015) 78-97.

[11] H.-S. Chang, K.-H. Choo, B. Lee, S.-J. Choi, The methods of identification, analysis, and removal of endocrine disrupting compounds (EDCs) in water, J. Hazard. Mater., 172 (2009) 1-12.

[12] M. Petrovic, E. Eljarrat, M.J. López de Alda, D. Barceló, Recent advances in the mass spectrometric analysis related to endocrine disrupting compounds in aquatic environmental samples, J. Chromatogr. A, 974 (2002) 23-51.

[13] R.A. Trenholm, B.J. Vanderford, J.C. Holady, D.J. Rexing, S.A. Snyder, Broad range analysis of endocrine disruptors and pharmaceuticals using gas chromatography and liquid chromatography tandem mass spectrometry, Environ. Chem. 65 (2006) 1990-1998.

[14] T.P. Wood, C.S.J. Duvenage, E. Rohwer, The occurrence of anti-retroviral compounds used for HIV treatment in South African surface water, Environ. Pollut., 199 (2015) 235-243.

[15] E. Van Hoeck, F. Canale, C. Cordero, S. Compernolle, C. Bicchi, P. Sandra, Multiresidue screening of endocrine-disrupting chemicals and pharmaceuticals in aqueous samples by multi-stir bar sorptive extraction-single desorption-capillary gas chromatography/mass spectrometry, Anal. Bioanal. Chem., 393 (2009) 907-919.

[16] M. Anastassiades, S.J. Lehotay, D. Štajnbaher, F.J. Schenck, Fast and easy multiresidue method employing acetonitrile extraction/partitioning and "dispersive solid-phase extraction" for the determination of pesticide residues in produce, J. AOAC Int., 86 (2003) 412-431.

[17] E. Matisová, S. Hrouzková, Analysis of endocrine disrupting pesticides by capillary GC with mass spectrometric detection, Int. J. Env. Res. Public Health, 9 (2012) 3166-3196.

[18] E. Baltussen, C. Cramers, P. Sandra, Sorptive sample preparation - a review, Anal. Bioanal. Chem., 373 (2002) 3-22.

[19] C.L. Arthur, J. Pawliszyn, Solid phase microextraction with thermal desorption using fused silica optical fibers, Anal. Chem., 62 (1990) 2145-2148. 
[20] E. Baltussen, P. Sandra, F. David, C. Cramers, Stir bar sorptive extraction (SBSE), a novel extraction technique for aqueous samples: theory and principles, J. Microcolumn Sep., 11 (1999) 737-747.

[21] S. Triñanes, M.T. Pena, M.C. Casais, M.C. Mejuto, Development of a new sorptive extraction method based on simultaneous direct and headspace sampling modes for the screening of polycyclic aromatic hydrocarbons in water samples, Talanta, 132 (2015) 433-442.

[22] N. Ochiai, K. Sasamoto, K. Hirooki, E. Pfannkoch, A Novel Extraction Procedure for Stir Bar Sorptive Extraction (SBSE): Sequential SBSE for Uniform Enrichment of Organic Pollutants in Water Samples. http://www.gerstel.com/pdf/p-gc-an-2008-12corrected.pdf, 2008 (accessed 15.11.2016) [23] M. Farré, L. Kantiani, M. Petrovic, S. Pérez, D. Barceló, Achievements and future trends in the analysis of emerging organic contaminants in environmental samples by mass spectrometry and bioanalytical techniques, J. Chromatogr. A, 1259 (2012) 86-99.

[24] C. Boix, M. Ibáñez, J.V. Sancho, J. Rambla, J.L. Aranda, S. Ballester, F. Hernández, Fast determination of 40 drugs in water using large volume direct injection liquid chromatographytandem mass spectrometry, Talanta, 131 (2015) 719-727.

[25] A. Masiá, J. Campo, C. Blasco, Y. Picó, Ultra-high performance liquid chromatographyquadrupole time-of-flight mass spectrometry to identify contaminants in water: An insight on environmental forensics, J. Chromatogr. A, 1345 (2014) 86-97.

[26] M.M. Bueno, M.M. Ulaszewska, M. Gomez, M. Hernando, A. Fernández-Alba, Simultaneous measurement in mass and mass/mass mode for accurate qualitative and quantitative screening analysis of pharmaceuticals in river water, J. Chromatogr. A, 1256 (2012) 80-88.

[27] A.C. Chiaia, C. Banta-Green, J. Field, Eliminating solid phase extraction with large-volume injection LC/MS/MS: Analysis of illicit and legal drugs and human urine indicators in US wastewaters, Environ. Sci. Technol., 42 (2008) 8841-8848.

[28] S. Bayen, X. Yi, E. Segovia, Z. Zhou, B.C. Kelly, Analysis of selected antibiotics in surface freshwater and seawater using direct injection in liquid chromatography electrospray ionization tandem mass spectrometry, J. Chromatogr. A, 1338 (2014) 38-43.

[29] Y. Naudé, E.R. Rohwer, Two multidimensional chromatographic methods for enantiomeric analysis of $o, p^{\prime}$-DDT and o, $p^{\prime}$-DDD in contaminated soil and air in a malaria area of South Africa, Anal. Chim. Acta, 730 (2012) 120-126.

[30] Y. Naudé, E.R. Rohwer, Novel method for determining DDT in vapour and particulate phases within contaminated indoor air in a malaria area of South Africa, Anal. Chim. Acta, 730 (2012) 112119.

[31] Y. Naude, M.W. Van Rooyen, E.R. Rohwer, Evidence for a geochemical origin of the mysterious circles in the Pro-Namib desert, J. Arid Environ., 75 (2011) 446-456.

[32] Y. Naudé, P. Gorst-Allman, E. Rohwer, A cheap and simple passive sampler using silicone rubber for the analysis of surface water by gas chromatography-time of flight mass spectrometry, Water SA: WISA 2014-Water Innovations Special Edition, 41 (2015) 182-188.

[33] M.G. Pintado-Herrera, E. González-Mazo, P.A. Lara-Martín, Atmospheric pressure gas chromatography-time-of-flight-mass spectrometry (APGC-ToF-MS) for the determination of regulated and emerging contaminants in aqueous samples after stir bar sorptive extraction (SBSE), Anal. Chim. Acta, 851 (2014) 1-13.

[34] H. van Den Dool, P. Dec. Kratz, A generalization of the retention index system including linear temperature programmed gas-liquid partition chromatography, J. Chromatogr. A, 11 (1963) 463471.

[35] M. Wooding, E.R. Rohwer, Y. Naudé, Comparison of a novel disposable sorptive sampler to stir bar sorptive extraction for the determination of micropollutants in surface water using thermal desorption with comprehensive gas chromatography - time-of-flight mass spectrometry, submitted to Analytica Chimica Acta, March 2017. 
[36] T. Colborn, TEDX list of potential endocrine disruptors, the endocrine disruptor exchange. http://endocrinedisruption.org/endocrine-disruption/tedx-list-of-potential-endocrinedisruptors/chemicalsearch, (accessed 16.02.15) [37] D. Montes-Grajales, J. Olivero-Verbel, EDCs DataBank: 3D-Structure database of endocrine disrupting chemicals, Toxicology, 327 (2015) 87-94.

[38] EU, Drinking Water Directive (Council Directive 98/83/EC of 3 November 1998 on the quality of water intended for human consumption). Brussels, Belgium.

http://ec.europa.eu/environment/water/water-drink/legislation_en.html, 1998 (accessed 16.08.05) [39] WHO, Guidelines for drinking-water quality 4th edition. Geneva, Switzerland.

http://www.who.int/water_sanitation_health/publications/2011/dwq_guidelines/en/, 2011 (accessed 16.08.05)

[40] EPA, US Environmental Protection Agency: Drinking Water Contaminants.

https://www.epa.gov/ground-water-and-drinking-water/table-regulated-drinking-watercontaminants, (accessed 16.08.04)

[41] UNEP, Stockholm Convention on Persistent Organic Pollutants (POPs), in: Conference of the Parties at its fourth meeting, Geneva, Switzerland, 2009.

[42] T. Kruger, I. Barnhoorn, J. Jansen van Vuren, R. Bornman, The use of the urogenital papillae of male feral African sharptooth catfish (Clarias gariepinus) as indicator of exposure to estrogenic chemicals in two polluted dams in an urban nature reserve, Gauteng, South Africa, Ecotoxicol. Environ. Saf., 87 (2013) 98-107.

\section{Figure captions}

Figure 1. Disposable PDMS sampling loop: a $10 \mathrm{~cm}$ length of a silicone elastomer medical grade tubing joined at the ends by a $1 \mathrm{~cm}$ piece of uncoated silica capillary column. See section 2.5.1. The $3 \mathrm{~cm}$ paper clip is for size indication.

Figure 2. Sorption extraction: PDMS sampling loop secured to a glass stir bar using stainless steel wire. See section 2.5.1.

Figure 3. GC inlet liner with two PDMS sampling loops (after sequential salting out extraction (2.5.1)) inserted for direct desorption inside a GC inlet of a GCxGC-TOFMS (2.6.1).

Figure 4. Contour plot of a reconstructed ion chromatogram (RIC) (GC $\times$ GC-TOFMS) of surface water collected at site 2 (Otter Bridge) in Rietvlei Nature Reserve. Target analytes detected are indicated. RIC: 246, 126, 194, 109, 270, 135, 181, 185, 162, 214, 97, 279 and $200 \mathrm{~m} / \mathrm{z}$.

Figure 5. LVI UHPLC base peak ion (BPI) chromatogram of surface water collected at site 4 (Rietvlei Spruit (spring)) in Rietvlei Nature Reserve (bottom trace); LVI UHPLC BPI chromatogram of a $5000 \mathrm{ng} / \mathrm{l}$ mixed reference standard (middle trace); LVI UHPLC RIC of $267.124 \mathrm{~m} / \mathrm{z}$ (nevirapine) from Rietvlei Spruit (top trace); APCl positive mode (QTOFMS/MS). Peak labels show retention time (minutes); $(M+H)^{+}$mass (Da).

\section{Supplementary material figure captions}


Figure A. Contour plot of a reconstructed ion chromatogram (RIC) (GC×GC-TOFMS) of a matrix blank (de-ionised water) used to prepare the matrix matched calibration standards. RIC: 246,126 , 194, 109, 270, 135, 181, 185, 162, 214, 97, 279 and $200 \mathrm{~m} / \mathrm{z}$.

Figure B. LVI UHPLC reconstructed ion chromatogram (RIC) of a matrix blank (de-ionised water) and LVI UHPLC RIC of a $5000 \mathrm{ng} / \mathrm{l}$ mixed matrix matched reference standard. RIC: $267.124 \mathrm{~m} / \mathrm{z}$ (nevirapine); $152.071 \mathrm{~m} / \mathrm{z}$ (Acetaminophen) $216.101 \mathrm{~m} / \mathrm{z}$ (Atrazine) APCl positive mode (QTOF$\mathrm{MS} / \mathrm{MS})$. Peak labels show retention time (minutes); $(\mathrm{M}+\mathrm{H})^{+}$mass $(\mathrm{Da})$.

\section{Supplementary Material}

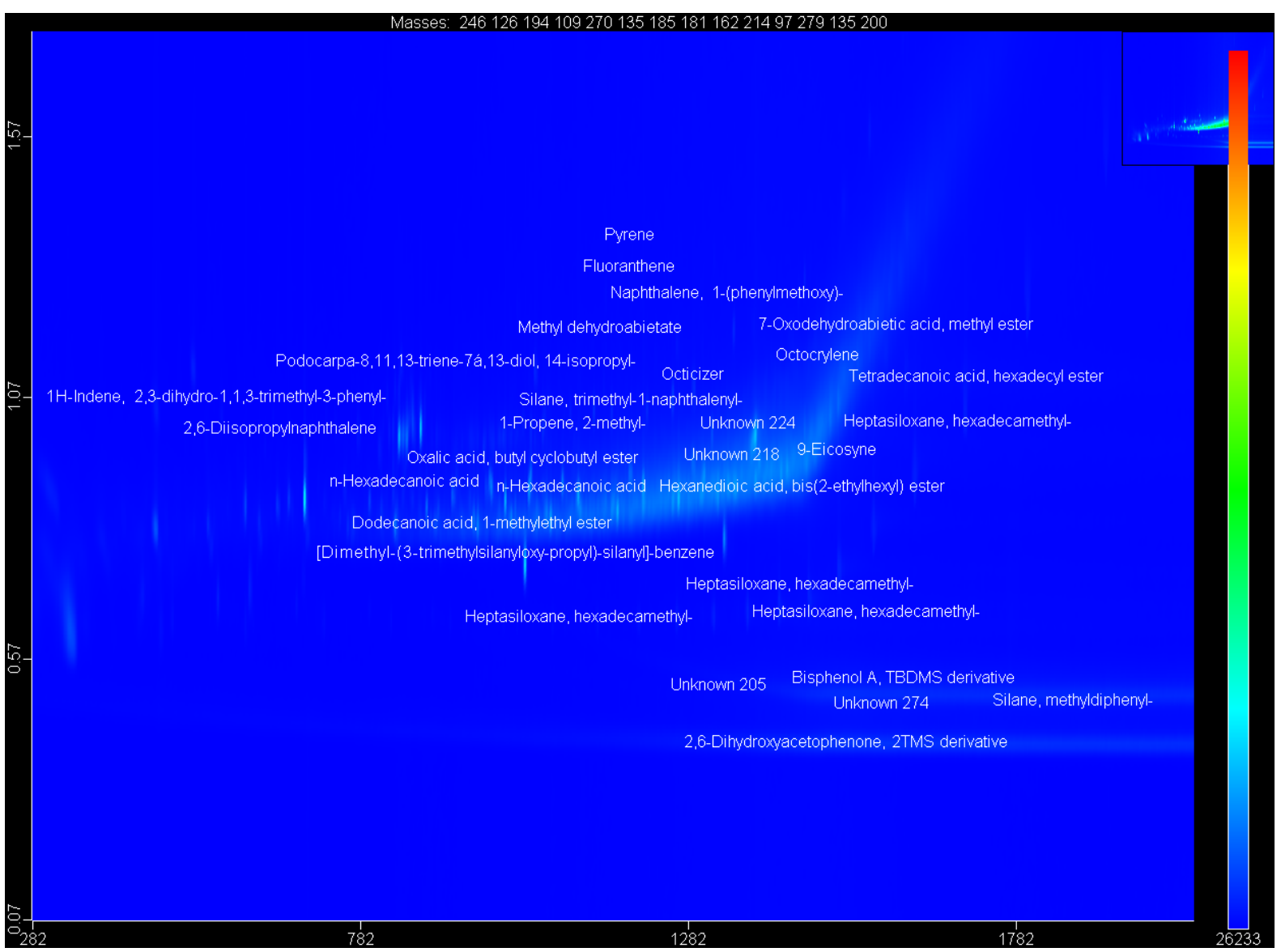

Figure A. Contour plot of a reconstructed ion chromatogram (RIC) (GC×GC-TOFMS) of a matrix blank (de-ionised water) used to prepare the matrix matched calibration standards. RIC: 246,126 , 194, 109, 270, 135, 181, 185, 162, 214, 97, 279 and $200 \mathrm{~m} / \mathrm{z}$. 
pestin AP wes:

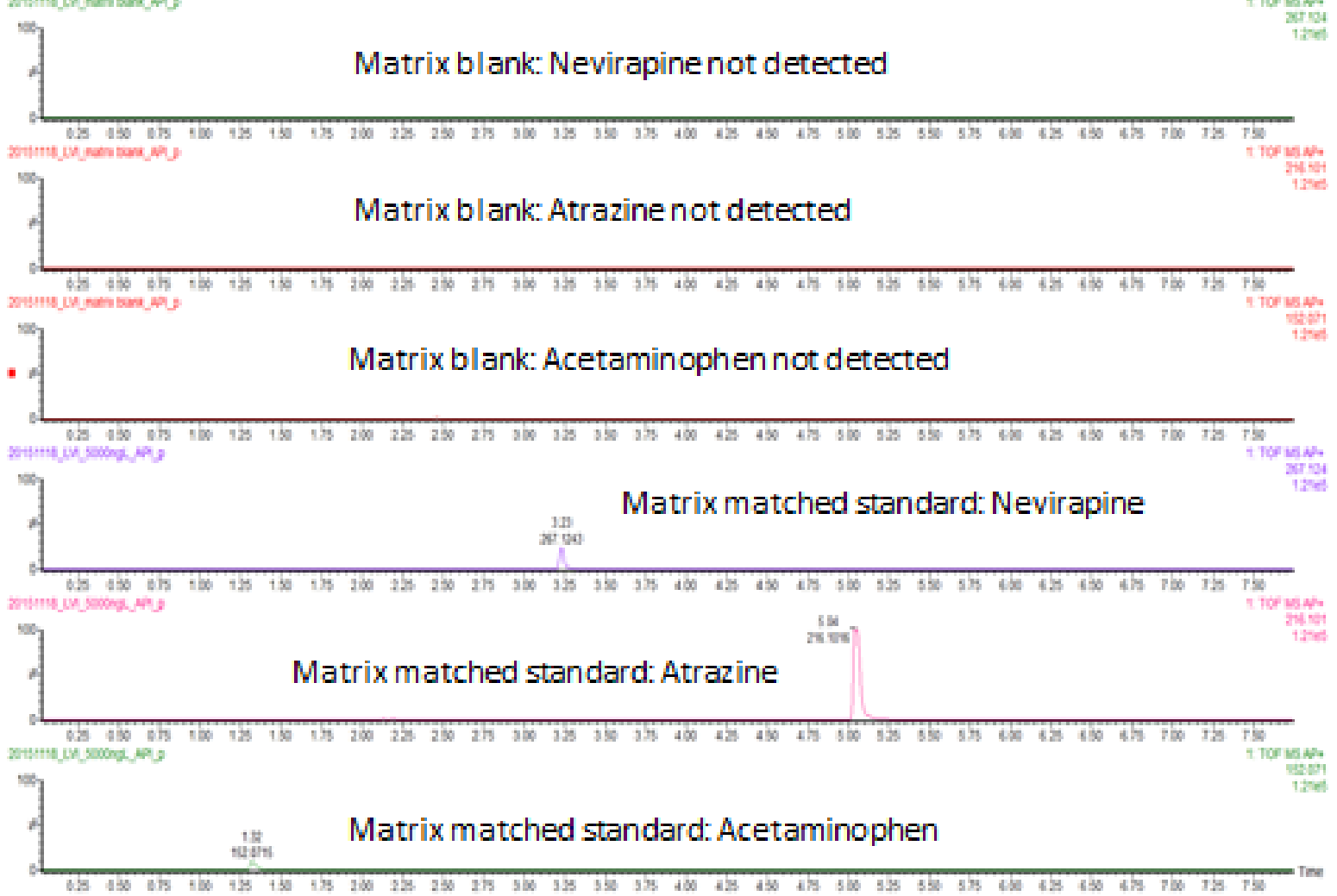

Supplementary material. Figure B. LVI UHPLC reconstructed ion chromatogram (RIC) of a matrix blank (de-ionised water) and LVI UHPLC RIC of a $5000 \mathrm{ng} / \mathrm{l}$ mixed matrix matched reference standard. RIC: $267.124 \mathrm{~m} / \mathrm{z}$ (nevirapine); $152.071 \mathrm{~m} / \mathrm{z}$ (Acetaminophen) $216.101 \mathrm{~m} / \mathrm{z}$ (Atrazine) APCI positive mode (QTOF-MS/MS). Peak labels show retention time (minutes); $(M+H)^{+}$mass (Da). 